\title{
Evaluation of a Zirconium Additive for the Mitigation of Molten Ash Formation During Combustion of Residual Fuel Oil
}

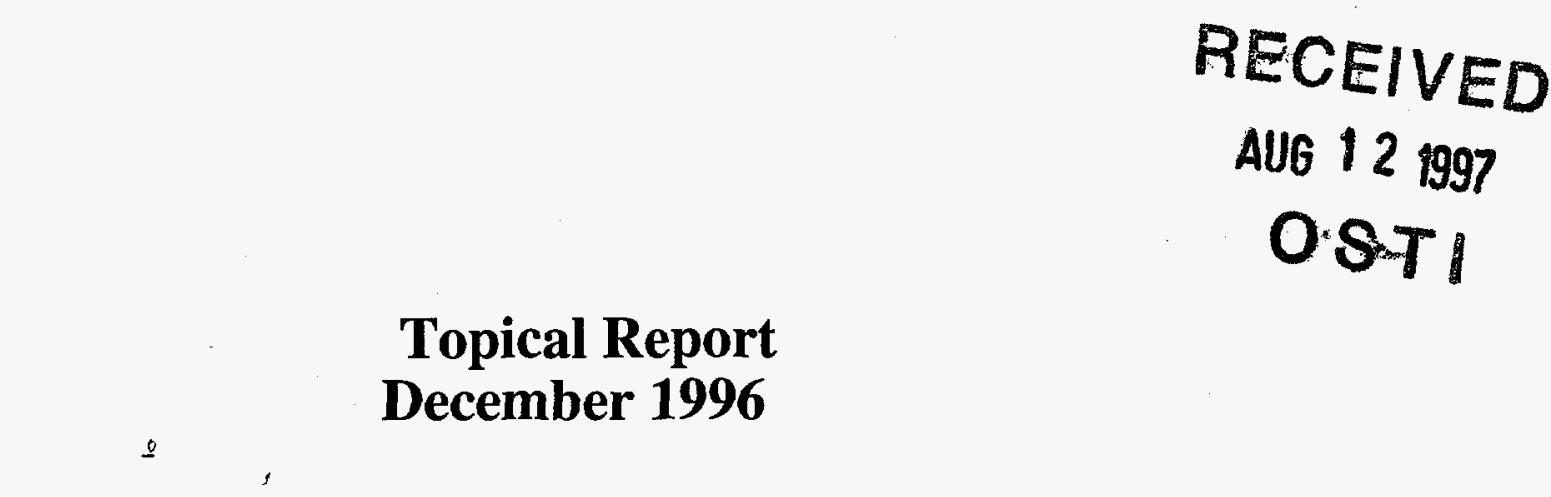

Work Performed Under Contract No.: DE-FC21-93MC30098

For

U.S. Department of Energy

Office of Fossil Energy

Federal Energy Technology Center

Morgantown Site

P.O. Box 880

Morgantown, West Virginia 26507-0880

DSTRIBUTION OF THIS DOCIMENT IS UAHEMTED

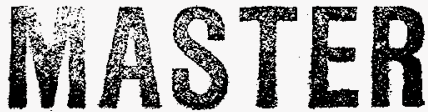

By

Energy \& Environmental Research Center

University of North Dakota

15 North 23rd Street

P.O. Box 9018

Grand Forks, North Dakota 58202-9018 


\section{Disclaimer}

This report was prepared as an account of work sponsored by an agency of the United States Government. Neither the United States Government nor any agency thereof, nor any of their employees, makes any warranty, express or implied, or assumes any legal liability or responsibility for the accuracy, completeness, or usefulness of any information, apparatus, product, or process disclosed, or represents that its use would not infringe privately owned rights. Reference herein to any specific commercial product, process, or service by trade name, trademark, manufacturer, or otherwise does not necessarily constitute or imply its endorsement, recommendation, or favoring by the United States Government or any agency thereof. The views and opinions of authors expressed herein do not necessarily state or reflect those of the United States Government or any agency thereof. 


\section{DISCLAIMER}

Portions of this document may be illegible electronic image products. Images are produced from the best available original document. 


\section{TABLE OF CONTENTS}

LIST OF FIGURES $\ldots \ldots \ldots \ldots \ldots \ldots \ldots \ldots \ldots \ldots \ldots \ldots \ldots \ldots \ldots \ldots \ldots$

LIST OF TABLES $\ldots \ldots \ldots \ldots \ldots \ldots \ldots \ldots \ldots \ldots \ldots \ldots \ldots \ldots \ldots$ iii

1.0 INTRODUCTION $\ldots \ldots \ldots \ldots \ldots \ldots \ldots \ldots \ldots \ldots \ldots \ldots \ldots \ldots \ldots$

2.0 BACKGROUND $\ldots \ldots \ldots \ldots \ldots \ldots \ldots \ldots \ldots \ldots \ldots \ldots \ldots$

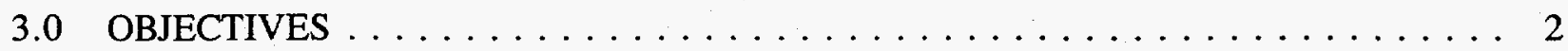

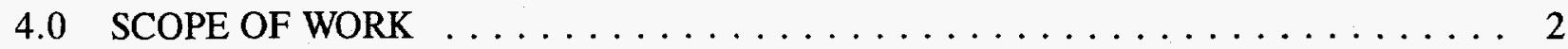

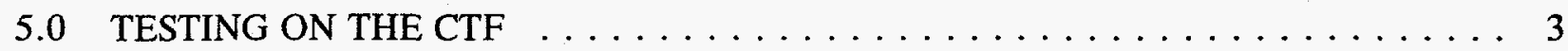

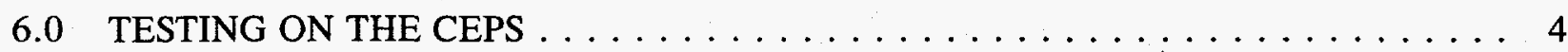

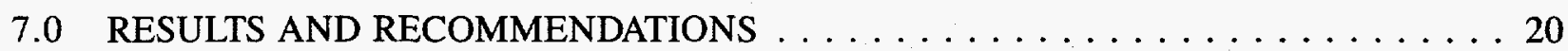

DESCRIPTION OF THE COMBUSTION TEST FACILITY (CTF) AND

EXPERIMENTAL PROCEDURES FOR COAL-WATER FUEL COMBUSTION . . . Appendix A DESCRIPTION OF THE CONVERSION AND ENVIRONMENTAL PROCESS SIMULATOR (CEPS) Appendix B 


\section{LIST OF FIGURES}

1 Molten ash deposits $\ldots \ldots \ldots \ldots \ldots \ldots \ldots \ldots \ldots \ldots \ldots \ldots \ldots$

2 Water-cooled wall probe $\ldots \ldots \ldots \ldots \ldots \ldots \ldots \ldots \ldots \ldots \ldots$

3 Water-cooled horizontal probe $\ldots \ldots \ldots \ldots \ldots \ldots \ldots \ldots \ldots \ldots$

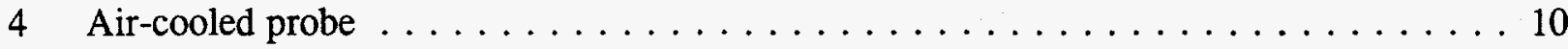

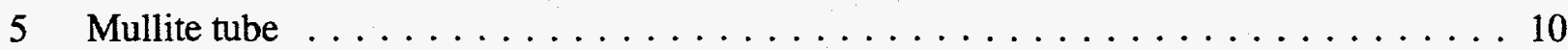

6 CTF combustor showing wall (left side) and horizontal (right side) probe locations . . . . 11

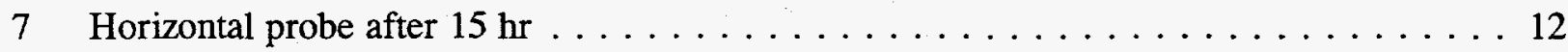

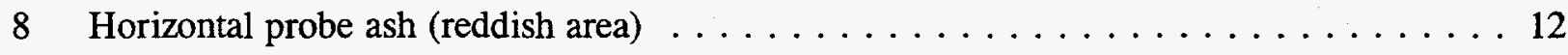

9 Horizontal probe ash (bottom area) $\ldots \ldots \ldots \ldots \ldots \ldots \ldots \ldots \ldots \ldots \ldots \ldots \ldots$

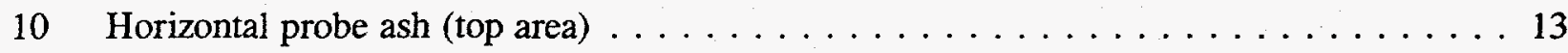

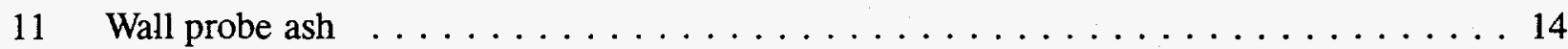

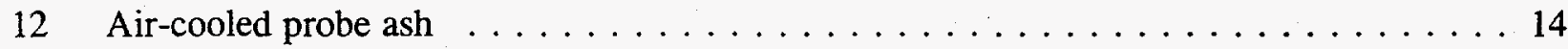

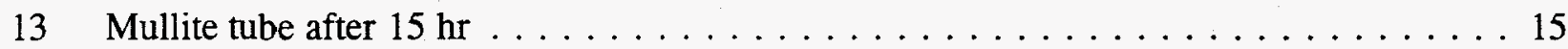

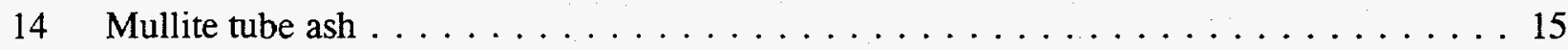

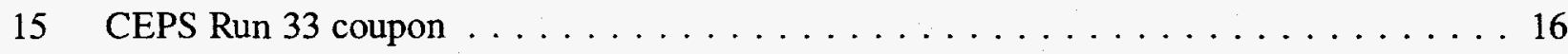

16 CEPS Run 33 coupon showing slag droplet in scraped area $\ldots \ldots \ldots \ldots \ldots \ldots$

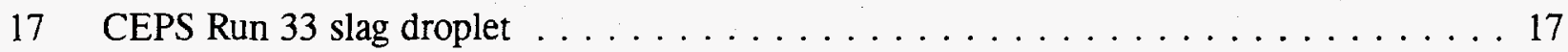

18 CEPS Run 34 deposit probe with coupon attached $\ldots \ldots \ldots \ldots \ldots \ldots \ldots \ldots$

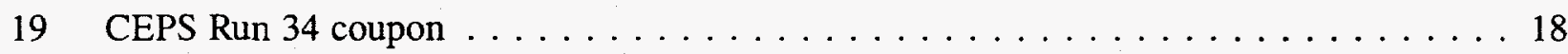

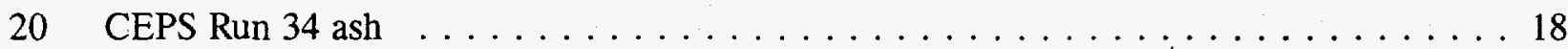




\section{LIST OF TABLES}

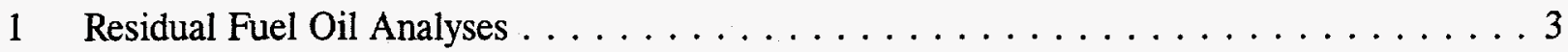

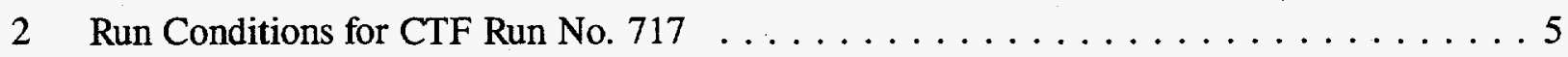

3 Run Conditions for CTF Run No. $718 \ldots \ldots \ldots \ldots \ldots \ldots \ldots \ldots$

4 Run Conditions for CEPS Runs 33 and $34 \ldots \ldots \ldots \ldots \ldots \ldots$

5 FP\&L Riviera Plant Dust Collector Ash Analysis $\ldots \ldots \ldots \ldots \ldots$ 


\section{EVALUATION OF A ZIRCONIUM ADDITIVE FOR THE MITIGATION OF MOLTEN ASH FORMATION DURING COMBUSTION OF RESIDUAL FUEL OIL}

\subsection{INTRODUCTION}

Florida Power \& Light Company (FP\&L) currently fires a residual fuel oil (RFO) containing catalyst fines, which results in a troublesome black aluminosilicate liquid phase that forms on heattransfer surfaces, remains molten, and flows to the bottom of the boiler. When the unit is shut down for a scheduled outage, this liquid phase freezes to a hard black glass that damages the contracting waterwalls of the boiler. Cleaning the boiler bottom and repairing damaged surfaces increase the boiler downtime, at a significant cost to FP\&L. The Energy \& Environmental Research Center (EERC) proposed to perform a series of tests for FP\&L to evaluate the effectiveness of a zirconium additive to modify the mechanism that forms this liquid phase, resulting in the formation of a dry refractory phase that may be easily handled during cleanup of the boiler.

\subsection{BACKGROUND}

Since 1984, FP\&L has experienced significant slagging problems in some of their oil-fired units, resulting from impurities in the residual fuel oil that is fired. Figure 1 illustrates the nature of these deposits, which are composed of mainly catalyst fines that are remnant aluminosilicate zeolites, vanadium, sodium, iron, and nickel. A laboratory study was performed during the latter part of 1984 and into 1985 to characterize these deposits and determine the effect of using $\mathrm{MgO}$ to mitigate this problem. Some success was noted when large quantities of $\mathrm{MgO}$ were added;

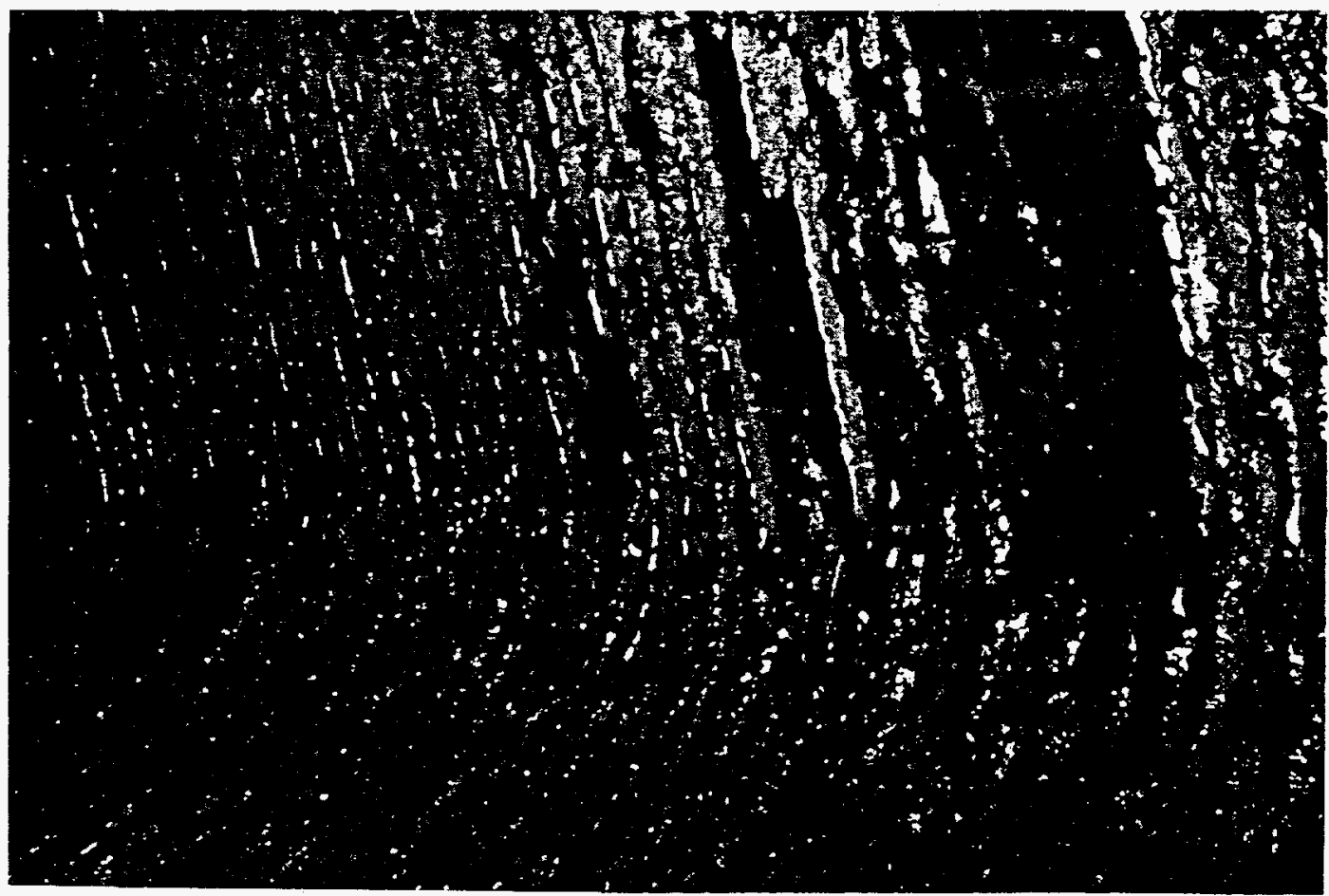

Figure 1. Molten ash deposits. 
however, sintered deposits formed, reducing heat transfer through the boiler. Since that time, FP\&L has used MgO in these units mainly to prevent the formation of the highly corrosive, lowmelting-point vanadium phases. To accomplish this, $\mathrm{MgO}$ is added at a ratio consistent with the vanadium content of the oil. Current operation indicates that the formation of the troublesome molten ash persists.

Florida Power \& Light personnel have determined that under the high temperatures obtained in the flame, it is possible to alter the chemical composition of the fly ash by using zirconium. It is expected that a nonreflective refractory material may be formed that will not adhere to heat-transfer surfaces and can be easily removed during scheduled outages.

\subsection{OBJECTIVES}

The goal of the tests proposed was to evaluate the effectiveness of a zirconium additive to inhibit molten ash formation. Specific objectives to meet this goal included the following:

- Duplicate the combustion environment under which the molten ash forms. This would establish the length of the test period required to form a measurable quantity of the troublesome phase.

- Install sampling probes that simulate furnace heat-transfer surfaces for the collection of deposits.

- Perform a series of screening tests to be used to examine deposit characteristics with and without the addition of zirconium to the fuel.

- Document deposit characteristics and save deposits for future analysis.

- Provide recommendations relative to combustion conditions and additive ratio.

\subsection{SCOPE OF WORK}

The proposed screening tests were to be performed in the EERC's combustion pilot plant, utilizing the combustion test facility (CTF). The CTF is a refractory-lined, bottom-fired furnace sized to achieve firing rates between 550,000 and $750,000 \mathrm{Btu} / \mathrm{hr}$. The CTF, originally built to test pulverized coals, has been enhanced to expand its capabilities to test other fuels such as coal-water fuels and refuse-derived fuels. The balanced-draft unit is fully instrumented to characterize combustion conditions and utilizes a PC-based data acquisition system for data collection and storage. For this project, the equipment normally used to feed slurries was used to feed the fuel oil. A more complete description of the CTF utilizing coal-water fuels is included in Appendix A.

The project work scope was to consist of seven single-day tests: 2 days of baseline testing followed by 5 days of additive testing. Baseline tests would be used to determine the operating conditions required to simulate the formation of the troublesome black glass and the length of the test period required to form a measurable quantity of this liquid phase. The zirconium additive 
would be blended with the residual fuel oil at up to four specified ratios and tested over an 8-hr period in each of 4 days of testing. The furnace was to be operated at approximately $750,000 \mathrm{Btu} / \mathrm{hr}$ to achieve the high flame temperatures required, with excess air regulated to achieve $0.5 \% \mathrm{O}_{2}$ in the flue gas. Flame temperature was to be measured during each day of testing with a high-velocity thermocouple. The final day of testing would be reserved for verification of test results or to determine the effect of excess air on the formation of the molten black glass.

Deposits were to be collected on each of two water-cooled probes designed to simulate boiler waterwall surfaces. Each of the probes is fully instrumented to achieve control of the surface metal temperature. Deposit probe surface and water temperatures are stored in the system's PC-based data acquisition and control system. The deposits would be photographed, collected, and weighed at the completion of each test period and stored for future analysis by FP\&L or by the EERC. FP\&L Company was to provide the fuel analyses necessary to maintain combustion conditions for process control.

\subsection{TESTING ON THE CTF}

Approximately $4000 \mathrm{lb}$ (eight 55-gallon drums) of the residual fuel oil were shipped to the EERC for the testing. FP\&L supplied the RFO, complete with ultimate, heating value, and ash analyses (Table 1).

TABLE 1

Residual Fuel Oil Analyses

\begin{tabular}{lr}
\hline Component, wt\% & \\
Water & 1.1 \\
Sulfur & 0.97 \\
Ash & 0.08 \\
Carbon & 87.67 \\
Nitrogen & 0.23 \\
Hydrogen & 9.83 \\
Oxygen, by difference & 0.1 \\
\hline Metals, mg/kg & \\
Aluminum & 19 \\
Silicon & 41 \\
Iron & 37 \\
Nickel & 33 \\
Vanandium & 60 \\
Magnesium & 34 \\
Sodium & 128 \\
\hline API Gravity, ASTM D287 & 10.3 \\
Heat of Combustion, Btu/lb & 18188 \\
\hline
\end{tabular}


Three separate tests were conducted on the RFO in the CTF. A $\mathrm{Mg}(\mathrm{OH})_{2}$ solution was added to the oil as a stabilized water solution and mixed with barrel mixers prior to use to obtain a $1: 1$ ratio of $\mathrm{Mg}: \mathrm{V}$ on a weight basis or $0.0653 \mathrm{~g}$ of $\mathrm{Mg}(\mathrm{OH})_{2} / \mathrm{lb}$ of oil prior to testing. The samples prepared for each day of testing were transferred to a continuously stirred storage tank located above the feed pump. A dual-fluid nozzle was used to fire the fuel oil. A description of the nozzle is given in Appendix A. The first test was a shakedown run to verify the operation and feed of the oil. The second test (Run 717) lasted $7 \mathrm{hr}, 37 \mathrm{~min}$, during which $350 \mathrm{lb}$ of oil was fed for an overall firing rate of $46 \mathrm{lb} / \mathrm{hr}$ at $0.86 \% \mathrm{O}_{2}$. For the third test (Run 718), $300 \mathrm{lb}$ of oil was fed over $7 \mathrm{hr}, 23 \mathrm{~min}$ for an overall firing rate of $41 \mathrm{lb} / \mathrm{hr}$ at $0.81 \% \mathrm{O}_{2}$. Run conditions for Runs 717 and 718 are shown in Tables 2 and 3 , respectively.

For Run 717, several probes were used to collect ash/slag samples. A watercooled wall probe (Figure 2) was inserted in the lower furnace and controlled to an average surface temperature of approximately $1340^{\circ} \mathrm{F}$; a water-cooled, cylindrical, horizontal probe (Figure 3) was inserted in the mid section of the furnace and controlled to an average surface temperature of approximately $960^{\circ} \mathrm{F}$; and an air-cooled probe (Figure 4) was inserted at the furnace exit and controlled to a surface temperature of approximately $1100^{\circ} \mathrm{F}$. An additional uncooled mullite tube (Figure 5) was inserted into the upper furnace to collect slag. Figure 6 shows the locations of the horizontal and wall probes on the combustor. There was evidence of a thin deposit layer on the wall probe, which was gold in color with fine black spots. The air-cooled probe had a small amount of a dusty brown (tan) ash deposited, while the horizontal probe had a black, sooty carbon buildup earlier in the run and later had a portion covered by a gold-colored deposit. High-velocity thermocouple (HVT) readings in the flame zone averaged $2257^{\circ} \mathrm{F}$.

Run 718 was a continuation of Run 717 . The probes were put back into the furnace and were controlled to temperatures similar to those used for Run 717. After the run, photographs were taken of the deposits and samples were scraped from the probes and viewed under a microscope at a magnification of $70 \times$. Here there was greater evidence of slag formation than was visible to the naked eye. A set of photographs were also obtained under a different microscope at a lower magnification. Figures 7-14 are selected pictures of the various deposits collected at the end of Run 718.

\subsection{TESTING ON THE CEPS}

Two runs were performed on the conversion and environmental process simulator (CEPS), an intermediate $(40,000-\mathrm{Btu} / \mathrm{hr})$ testing furnace, which is externally heated by electrical elements. It is equipped with numerous sampling and optical ports throughout the system. A description of the CEPS is included in Appendix B. The runs were performed on this unit after initial testing on the CTF indicated that very little ash was collecting on the probes. The CEPS has the potential to form deposits in a shorter time while using very little fuel in comparison to the CTF. We also wanted to study the deposit formation in a combustor that can closely control the combustion environment to verify that the same types of deposits would be formed in a different environment. The deposits obtained from the CEPS testing were similar to the ones formed in the CTF. 
TABLE 2

Run Conditions for CTF Run 717

\begin{tabular}{|c|c|c|c|c|c|c|c|c|c|c|}
\hline Description & Units & $\begin{array}{l}\text { Avg., } \\
\text { overall }\end{array}$ & $\begin{array}{l}\text { Avg., } \\
\mathrm{Hr} 1 \\
\end{array}$ & $\begin{array}{l}\text { Avg., } \\
\mathrm{Hr} 2\end{array}$ & $\begin{array}{l}\text { Avg., } \\
\text { Hr } 3\end{array}$ & $\begin{array}{l}\text { Avg., } \\
\mathrm{Hr} 4 \\
\end{array}$ & $\begin{array}{l}\text { Avg., } \\
\mathrm{Hr} 5\end{array}$ & $\begin{array}{l}\text { Avg., } \\
\mathrm{Hr} 6 \\
\end{array}$ & $\begin{array}{l}\text { Avg., } \\
\mathrm{Hr} 7\end{array}$ & $\begin{array}{l}\text { Avg., } \\
\mathrm{Hr} 8 \\
\end{array}$ \\
\hline Primary Air & ${ }^{\circ} \mathrm{F}$ & 266 & 269 & 264 & 263 & 265 & 266 & 268 & 269 & 270 \\
\hline Secondary Air & ${ }^{\circ} \mathrm{F}$ & 672 & 672 & 671 & 671 & 671 & 671 & 673 & 674 & 674 \\
\hline Combustor N Exit & ${ }^{\circ} \mathrm{F}$ & 1926 & 1867 & 1911 & 1910 & 1965 & 1941 & 1934 & 1948 & 1946 \\
\hline $\begin{array}{l}\text { Combustor S Exit } \\
\text { (lower than } N \text { ) }\end{array}$ & ${ }^{\circ} \mathrm{F}$ & 2082 & 2023 & 2086 & 2079 & 2118 & 2087 & 2083 & 2095 & 2097 \\
\hline Total Air Flow & $\operatorname{scfm}$ & 105 & 106 & 106 & 106 & 106 & 105 & 105 & 105 & 105 \\
\hline Primary Air Flow & $\mathrm{scfm}$ & 18 & 18 & 18 & 18 & 18 & 18 & 18 & 18 & 18 \\
\hline Secondary Air Flow & $\operatorname{scfm}$ & 100 & 101 & 101 & 100 & 100 & 99 & 99 & 99 & 99 \\
\hline Atomizer Air Flow & $\operatorname{scfh}$ & 451 & 380 & 380 & 390 & 400 & 560 & 500 & 500 & 500 \\
\hline Total Flue Gas Flow & scfm & 141 & 139 & 144 & 141 & 140 & 140 & 140 & 142 & 144 \\
\hline Excess Air & $\%$ & 4.7 & 3.3 & 2.9 & 2.4 & 6.8 & 4.1 & 5.2 & 6.7 & 8.1 \\
\hline Fuel Firing Rate & $\mathrm{lb} / \mathrm{hr}$ & 46.6 & 47.5 & 43.3 & 47.0 & 47.0 & 47.0 & 47.0 & 47.0 & 47.0 \\
\hline Fuel Firing Rate & Btu/hr & 744845 & 750000 & 712193 & 750000 & 750000 & 750000 & 750000 & 750000 & 750000 \\
\hline Air Probe & ${ }^{\circ} \mathrm{F}$ & 1101 & 1143 & 1168 & 1194 & 1088 & 978 & 1062 & 1037 & 1204 \\
\hline $\begin{array}{l}\text { Horizontal Slag Probe, } \\
\text { bottom }\end{array}$ & ${ }^{\circ} \mathrm{F}$ & 1015 & 1005 & 1019 & 1054 & 1034 & 1014 & 1013 & 983 & 971 \\
\hline $\begin{array}{l}\text { Horizontal Slag Probe, } \\
\text { right side }\end{array}$ & ${ }^{\circ} \mathrm{F}$ & 932 & 902 & 938 & 964 & 946 & 928 & 936 & 921 & 908 \\
\hline $\begin{array}{l}\text { Horizontal Slag Probe, } \\
\text { left side }\end{array}$ & ${ }^{\circ} \mathrm{F}$ & 949 & 925 & 954 & 984 & 971 & 948 & 947 & 925 & 914 \\
\hline
\end{tabular}


TABLE 2 (continued)

\begin{tabular}{|c|c|c|c|c|c|c|c|c|c|c|}
\hline Description & Units & $\begin{array}{l}\text { Avg., } \\
\text { overall }\end{array}$ & $\begin{array}{l}\text { Avg., } \\
\mathrm{Hr} 1\end{array}$ & $\begin{array}{l}\text { Avg., } \\
\mathrm{Hr} 2\end{array}$ & $\begin{array}{l}\text { Avg., } \\
\mathrm{Hr} 3\end{array}$ & $\begin{array}{l}\text { Avg., } \\
\mathrm{Hr} 4\end{array}$ & $\begin{array}{l}\text { Avg., } \\
\text { Hr } 5\end{array}$ & $\begin{array}{l}\text { Avg., } \\
\text { Hr } 6\end{array}$ & $\begin{array}{l}\text { Avg., } \\
\mathrm{Hr} 7\end{array}$ & $\begin{array}{l}\text { Avg. } \\
\text { Hr } 8\end{array}$ \\
\hline $\begin{array}{l}\text { Wall Probe Surface } \\
\text { Metal } 1\end{array}$ & ${ }^{\circ} \mathrm{F}$ & 1313 & 1310 & 1320 & 1315 & 1271 & 1327 & 1322 & 1322 & 1314 \\
\hline $\begin{array}{l}\text { Wall Probe Surface } \\
\text { Metal } 2\end{array}$ & ${ }^{\circ} \mathrm{F}$ & 1369 & 1381 & 1379 & 1370 & 1311 & 1375 & 1381 & 1380 & 1384 \\
\hline $\begin{array}{l}\text { Wall Probe Inside } \\
\text { Metal } 1\end{array}$ & ${ }^{\circ} \mathrm{F}$ & 1153 & 1140 & 1152 & 1138 & 1090 & 1176 & 1184 & 1184 & 1171 \\
\hline $\begin{array}{l}\text { Wall Probe Inside } \\
\text { Metal } 2\end{array}$ & ${ }^{\circ} \mathrm{F}$ & 1366 & 1319 & 1378 & 1357 & 1338 & 1366 & 1393 & 1403 & 1378 \\
\hline Flue Gas $\mathrm{A} \mathrm{O}_{2}$ & $\%$ & 0.86 & 0.69 & 0.63 & 0.51 & 0.62 & 0.88 & 1.04 & 1.35 & 1.59 \\
\hline Flue Gas $\mathrm{B} \mathrm{O}_{2}$ & $\%$ & 1.83 & 1.59 & 1.78 & 1.50 & 1.71 & 1.75 & 2.06 & 2.19 & 2.37 \\
\hline Flue Gas $\mathrm{A} \mathrm{CO}_{2}$ & $\%$ & 14.62 & 14.25 & 14.39 & 14.35 & 14.14 & 14.17 & 15.19 & 15.49 & 15.30 \\
\hline Flue Gas $\mathrm{B} \mathrm{CO}_{2}$ & $\%$ & 15.77 & 15.48 & 15.54 & 15.45 & 14.98 & 16.93 & 15.98 & 15.78 & 15.50 \\
\hline Flue Gas $\mathrm{A} \mathrm{SO}_{2}$ & $\mathrm{ppm}$ & 570 & 524 & 553 & 615 & 601 & 573 & 564 & 563 & 579 \\
\hline Flue Gas $\mathrm{B} \mathrm{SO}_{2}$ & $\mathrm{ppm}$ & 537 & 527 & 544 & 565 & 556 & 551 & 528 & 487 & 546 \\
\hline Flue Gas A CO & $\mathrm{ppm}$ & 1 & 1 & 1 & 1 & 1 & 1 & 1 & 1 & 1 \\
\hline Flue Gas $\mathrm{NO}_{\mathrm{x}}$ & ppm & 192 & 181 & 191 & 180 & 171 & 214 & 216 & 192 & 181 \\
\hline HVT Flame Temp. & ${ }^{\circ} \mathrm{F}$ & 2257 & 2210 & 2250 & 2263 & 2267 & 2257 & 2267 & 2283 & NA* \\
\hline
\end{tabular}

* Not available. 
TABLE 3

Run Conditions for CTF Run 718

\begin{tabular}{|c|c|c|c|c|c|c|c|c|c|c|}
\hline Description & Units & $\begin{array}{l}\text { Avg., } \\
\text { overall }\end{array}$ & $\begin{array}{l}\text { Avg., } \\
\text { Hr } 1\end{array}$ & $\begin{array}{l}\text { Avg., } \\
\mathrm{Hr} 2 \\
\end{array}$ & $\begin{array}{l}\text { Avg., } \\
\mathrm{Hr} 3 \\
\end{array}$ & $\begin{array}{l}\text { Avg., } \\
\mathrm{Hr} 4\end{array}$ & $\begin{array}{l}\text { Avg., } \\
\text { Hr } 5\end{array}$ & $\begin{array}{l}\text { Avg., } \\
\text { Hr } 6\end{array}$ & $\begin{array}{l}\text { Avg., } \\
\mathrm{Hr} 7\end{array}$ & $\begin{array}{l}\text { Avg., } \\
\mathrm{Hr} 8\end{array}$ \\
\hline Primary Air & ${ }^{\circ} \mathrm{F}$ & 260 & 264 & 255 & 256 & 261 & 260 & 261 & 262 & 262 \\
\hline Secondary Air & ${ }^{\circ} \mathrm{F}$ & 676 & 677 & 675 & 675 & 676 & 676 & 677 & 676 & 676 \\
\hline Combustor N Exit & ${ }^{\circ} \mathrm{F}$ & 1992 & 1947 & 1982 & 1994 & 1995 & 2006 & 2005 & 2010 & 2002 \\
\hline $\begin{array}{l}\text { Combustor S (lower } \\
\text { than } N \text { ) }\end{array}$ & ${ }^{\circ} \mathrm{F}$ & 2143 & 2096 & 2135 & 2149 & 2146 & 2157 & 2155 & 2160 & 2150 \\
\hline Total Air Flow & $\operatorname{scfm}$ & 109 & 109 & 110 & 110 & 110 & 109 & 109 & 109 & 109 \\
\hline Primary Air Flow & $\mathrm{scfm}$ & 18 & 18 & 18 & 18 & 18 & 18 & 18 & 18 & 18 \\
\hline Secondary Air Flow & scfm & 104 & 104 & 105 & 105 & 104 & 104 & 104 & 104 & 103 \\
\hline Atomizer Air Flow & scfh & 600 & 600 & 600 & 600 & 600 & 600 & 600 & 600 & 600 \\
\hline Total Flue Gas Flow & scfm & 146 & 150 & 146 & 147 & 146 & 145 & 146 & 145 & 144 \\
\hline Excess Air & $\%$ & 4.2 & 3.2 & 3.5 & 4.3 & 3.9 & 5.7 & 4.1 & 3.9 & 6.0 \\
\hline Fuel Firing Rate & $\mathrm{lb} / \mathrm{hr}$ & 43.8 & 42.8 & 44.0 & 44.0 & 44.0 & 44.0 & 44.0 & 44.0 & 44.0 \\
\hline Firing Rate & $\mathrm{Btu} / \mathrm{hr}$ & 748711 & 740548 & 750000 & 750000 & 750000 & 750000 & 750000 & 750000 & 750000 \\
\hline Air Probe & ${ }^{\circ} \mathrm{F}$ & 1094 & 1018 & 1144 & 1103 & 1010 & 1017 & 1075 & 1240 & 1240 \\
\hline $\begin{array}{l}\text { Horizontal Slag Probe, } \\
\text { bottom }\end{array}$ & ${ }^{\circ} \mathrm{F}$ & 999 & 1000 & 1025 & 1022 & 1038 & 888 & 1017 & 1010 & 989 \\
\hline $\begin{array}{l}\text { Horizontal Slag Probe, } \\
\text { left side }\end{array}$ & ${ }^{\circ} \mathrm{F}$ & 937 & 941 & 961 & 959 & 963 & 829 & 954 & 954 & 939 \\
\hline
\end{tabular}


TABLE 3 (continued)

\begin{tabular}{|c|c|c|c|c|c|c|c|c|c|c|}
\hline Description & Units & $\begin{array}{l}\text { Avg., } \\
\text { overall }\end{array}$ & $\begin{array}{l}\text { Avg., } \\
\text { Hr } 1\end{array}$ & $\begin{array}{l}\text { Avg., } \\
\text { Hr } 2\end{array}$ & $\begin{array}{l}\text { Avg., } \\
\text { Hr } 3\end{array}$ & $\begin{array}{l}\text { Avg., } \\
\mathrm{Hr} 4\end{array}$ & $\begin{array}{l}\text { Avg., } \\
\text { Hr } 5\end{array}$ & $\begin{array}{l}\text { Avg., } \\
\text { Hr } 6\end{array}$ & $\begin{array}{l}\text { Avg., } \\
\text { Hr } 7\end{array}$ & $\begin{array}{l}\text { Avg., } \\
\text { Hr } 8\end{array}$ \\
\hline $\begin{array}{l}\text { Horizontal Slag Probe, } \\
\text { right side }\end{array}$ & ${ }^{\circ} \mathrm{F}$ & 927 & 932 & 954 & 948 & 964 & 823 & 942 & 934 & 912 \\
\hline $\begin{array}{l}\text { Wall Probe Surface } \\
\text { Metal } 1\end{array}$ & ${ }^{\circ} \mathrm{F}$ & 1274 & 1266 & 1315 & 1325 & 1286 & 1226 & 1261 & 1252 & 1235 \\
\hline $\begin{array}{l}\text { Wall Probe Surface } \\
\text { Metal } 2\end{array}$ & ${ }^{\circ} \mathrm{F}$ & 1422 & 1351 & 1413 & 1436 & 1444 & 1407 & 1449 & 1449 & 1440 \\
\hline $\begin{array}{l}\text { Wall Probe Inside } \\
\text { Metal } 1\end{array}$ & ${ }^{\circ} \mathrm{F}$ & 1193 & 1141 & 1204 & 1208 & 1208 & 1177 & 1207 & 1204 & 1197 \\
\hline $\begin{array}{l}\text { Wall Probe Inside } \\
\text { Metal } 2\end{array}$ & ${ }^{\circ} \mathrm{F}$ & 1406 & 1346 & 1416 & 1421 & 1424 & 1386 & 1424 & 1424 & 1413 \\
\hline Flue Gas $\mathrm{A} \mathrm{O}_{2}$ & $\%$ & 0.81 & 0.68 & 0.74 & 0.90 & 0.81 & 0.75 & 0.85 & 0.81 & 1.22 \\
\hline Flue Gas $\mathrm{B} \mathrm{O}_{2}$ & $\%$ & 1.74 & 1.61 & 1.66 & 1.84 & 1.71 & 1.68 & 1.75 & 1.79 & 2.10 \\
\hline Flue Gas $\mathrm{A} \mathrm{CO}_{2}$ & $\%$ & 15.88 & 15.97 & 16.01 & 15.79 & 16.28 & 15.93 & 15.64 & 15.69 & 15.44 \\
\hline Flue Gas $\mathrm{B} \mathrm{CO}_{2}$ & $\%$ & 15.1 & 14.02 & 12.88 & 16.39 & 16.05 & 15.86 & 15.82 & 15.69 & 15.73 \\
\hline Flue Gas $\mathrm{A} \mathrm{SO}_{2}$ & ppm & 580 & 536 & 587 & 588 & 583 & 597 & 588 & 586 & 571 \\
\hline Flue Gas $\mathrm{B} \mathrm{SO}_{2}$ & ppm & 602 & 842 & 558 & 568 & 579 & 572 & 559 & 553 & 548 \\
\hline Flue Gas A CO & ppm & 1 & 1 & 1 & 1 & 1 & 1 & 1 & 1 & 1 \\
\hline Flue Gas A NO & ppm & 213 & 196 & 194 & 215 & 205 & 210 & 219 & 240 & 254 \\
\hline HVT Flame Temp. & ${ }^{\circ} \mathrm{F}$ & NA* & NA & NA & NA & NA & NA & NA & NA & NA \\
\hline
\end{tabular}

* Not available. 


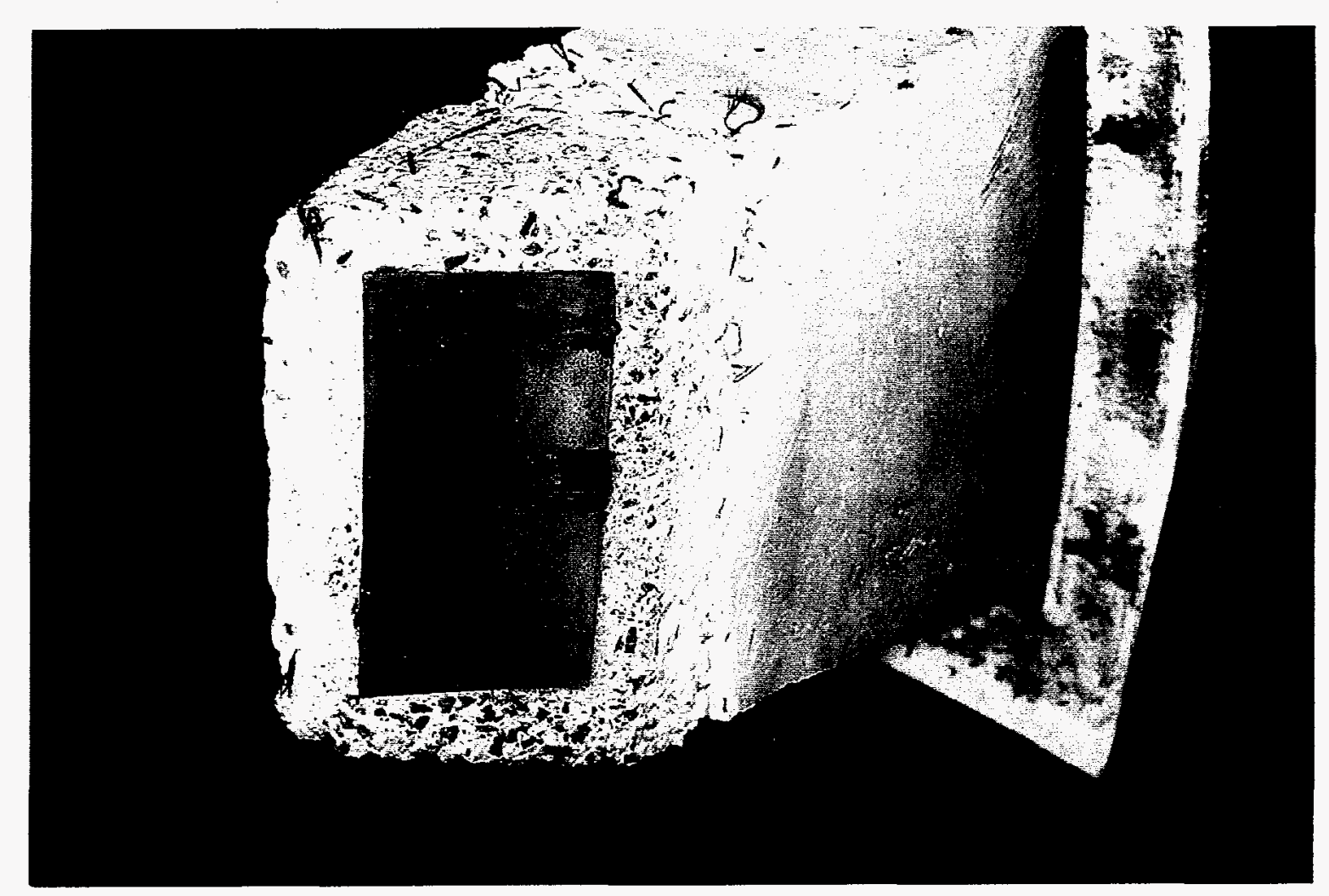

Figure 2. Water-cooled wall probe.

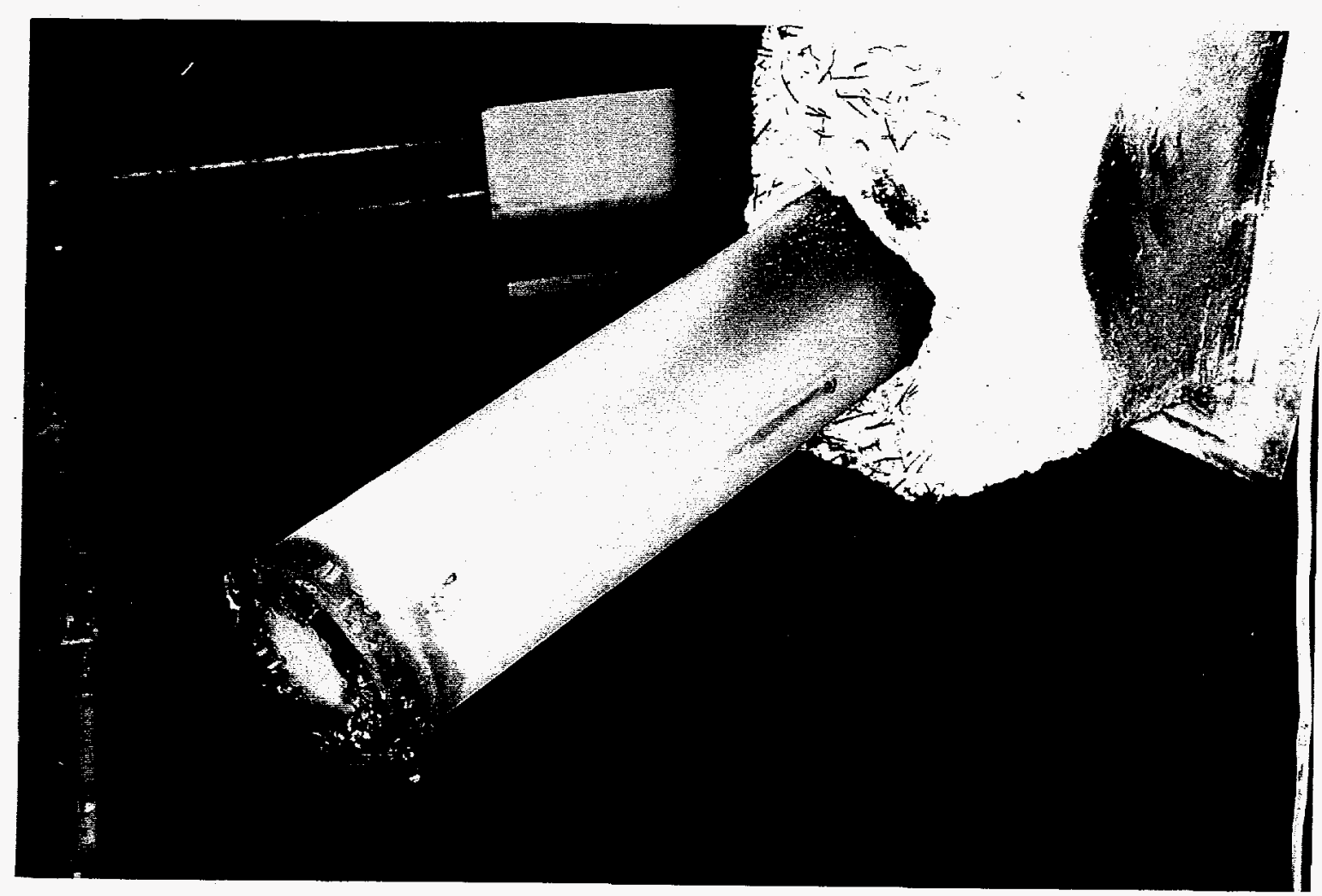

Figure 3. Water-cooled horizontal probe. 


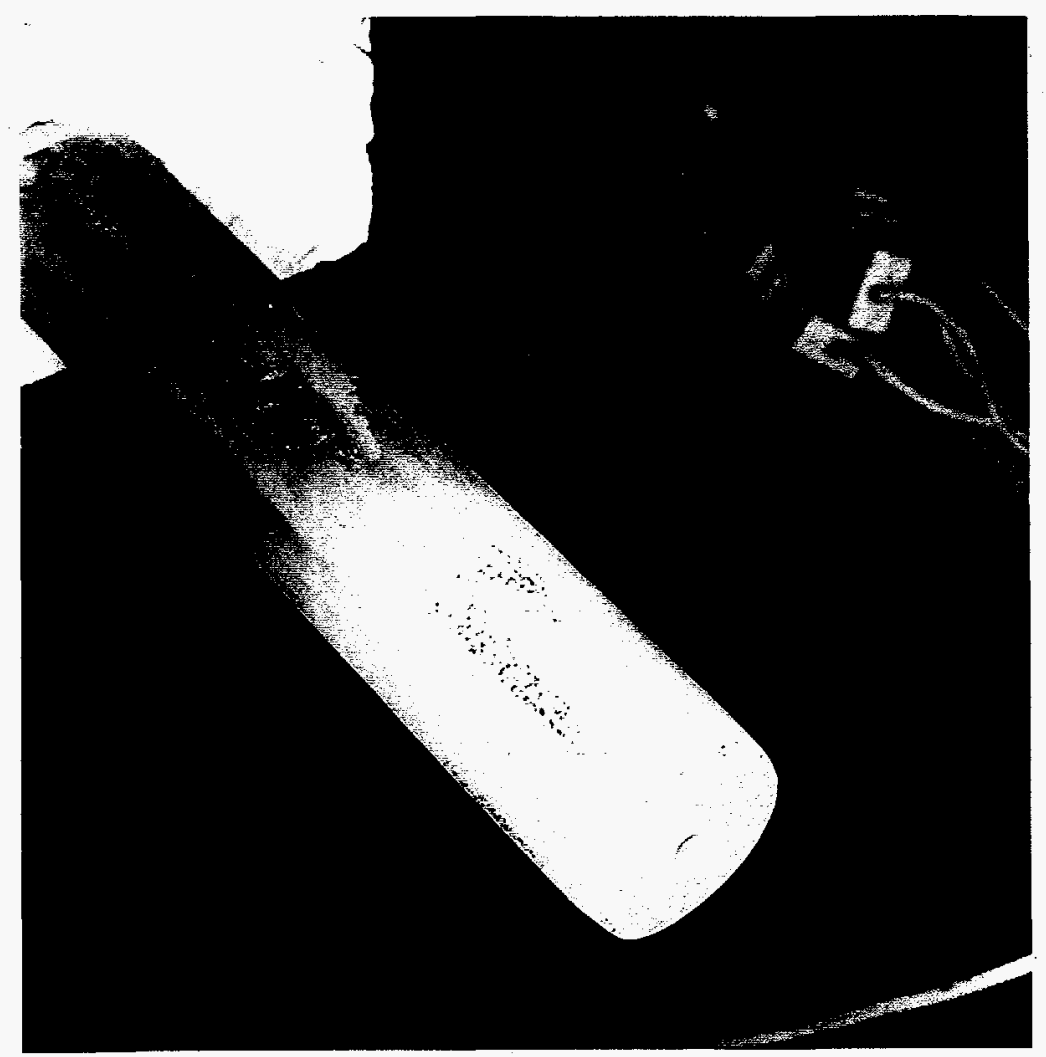

Figure 4. Air-cooled probe.

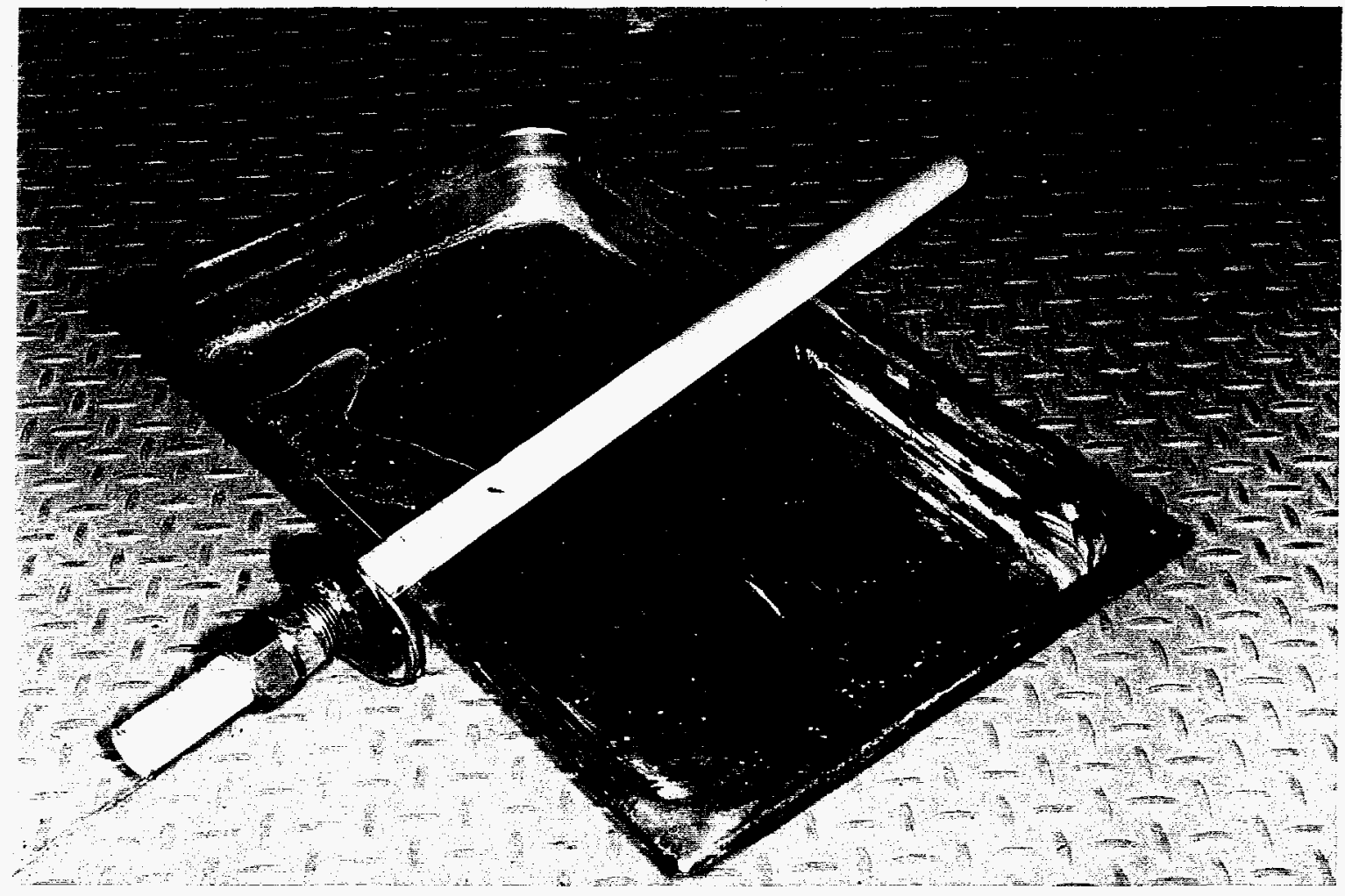

Figure 5. Mullite tube. 


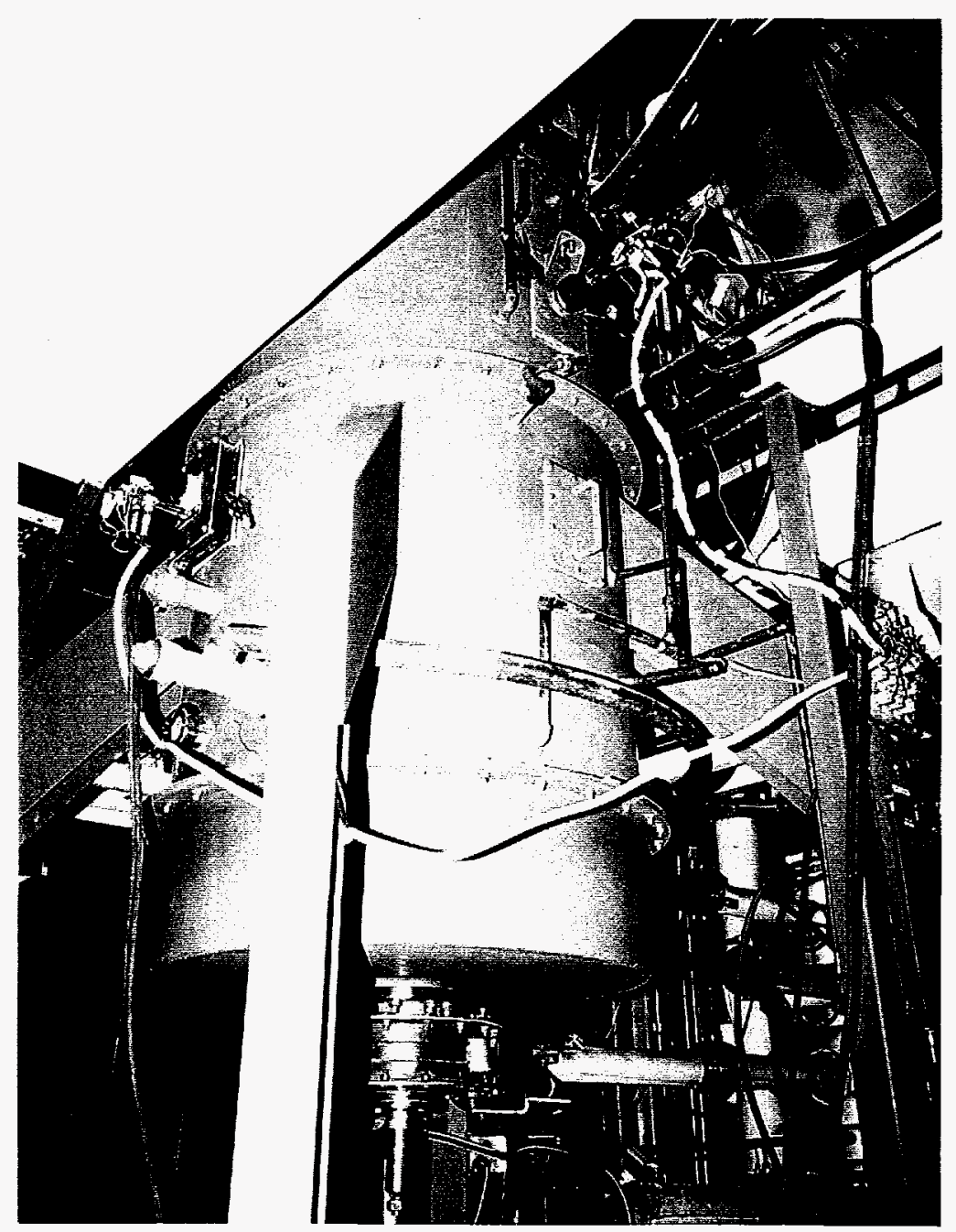

Figure 6. CTF combustor showing wall (left side) and horizontal (right side) probe locations.

For the first run (Run 33), a deposition probe was inserted for $3 \mathrm{hr}$, and for the second run (Run 34), the probe was inserted for $11 \mathrm{hr}, 15 \mathrm{~min}$. The deposition probe was inserted in the last heated section of the furnace (Section 7).

For Run 33 , the probe was controlled to $540^{\circ} \mathrm{C}\left(1004^{\circ} \mathrm{F}\right)$, and the furnace zone was heated to $1200^{\circ} \mathrm{C}\left(2192^{\circ} \mathrm{F}\right)$. The deposit that formed on the probe (Figure 15) was yellow in color with fine black particles. This ash adhered to the probe, and it had to be scraped to remove it. Figure 16 shows a slag drop that is tightly adhered to the deposit substrate (coupon) where the yellow ash layer has been scraped and brushed away, and Figure 17 is a closeup of that slag drop.

For Run 34, the furnace was controlled at $1300^{\circ} \mathrm{C}\left(2372^{\circ} \mathrm{F}\right)$ at this location (Furnace Section 7). For Run 34 , the probe was controlled to $640^{\circ} \mathrm{C}\left(1184^{\circ} \mathrm{F}\right)$ initially for the first $8 \mathrm{hr}$ and then lowered to $540^{\circ} \mathrm{C}\left(1004^{\circ} \mathrm{F}\right)$ for the remaining time. The probe temperature was lowered since there did not appear to be any significant increase in the deposit buildup compared to Run 33 and it was suspected that the temperature of the probe was too high for a sulfation layer to form. After the probe temperature was lowered, more ash was apparent on the probe. The deposit that formed was light to dark brown (Figures 18 and 19) and tightly adhered to the probe. The particles furthest away from the probe surface were molten (Figure 20). In a layer next to the surface, large black particles adhered to the probe. 


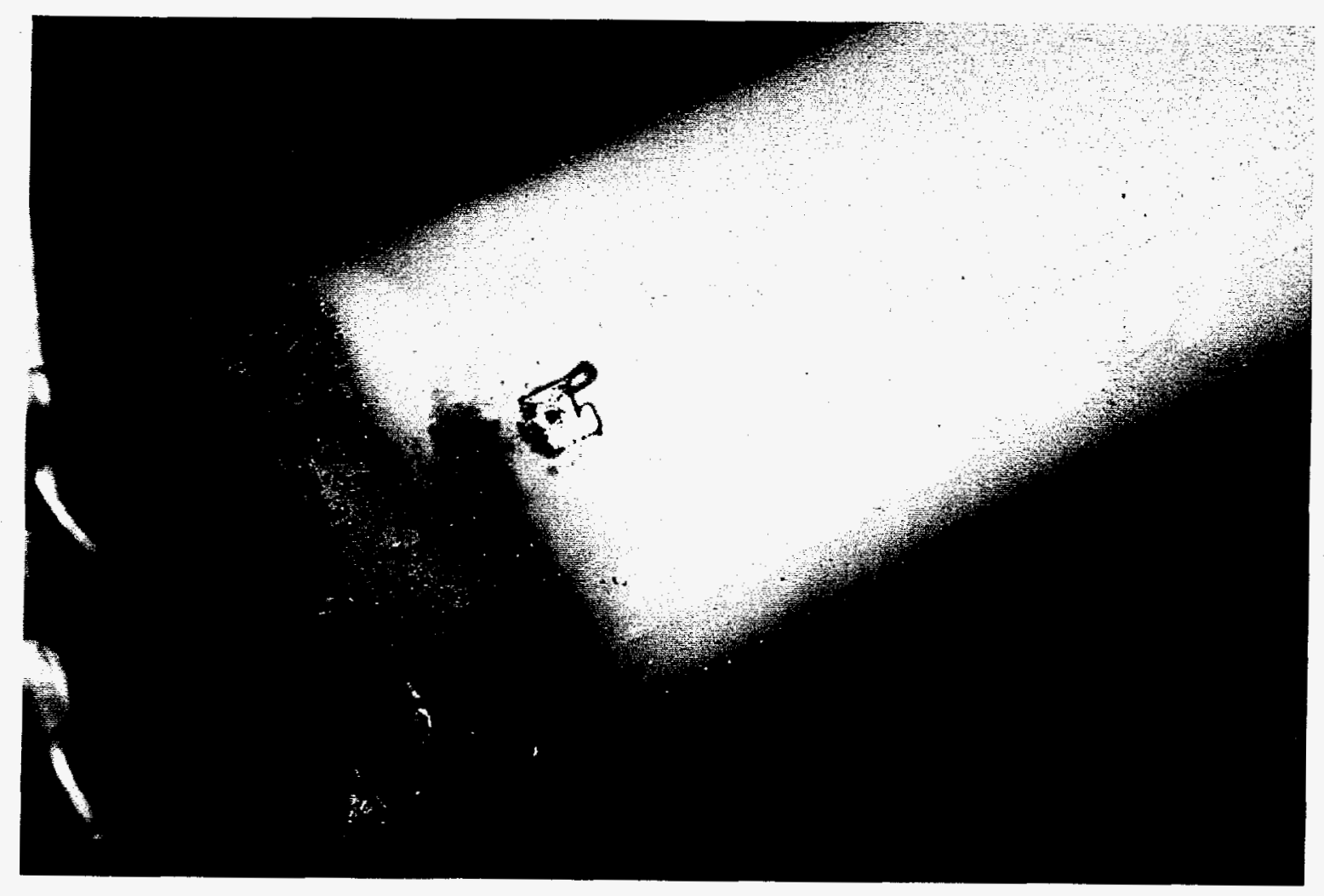

Figure 7. Horizontal probe after $15 \mathrm{hr}$.

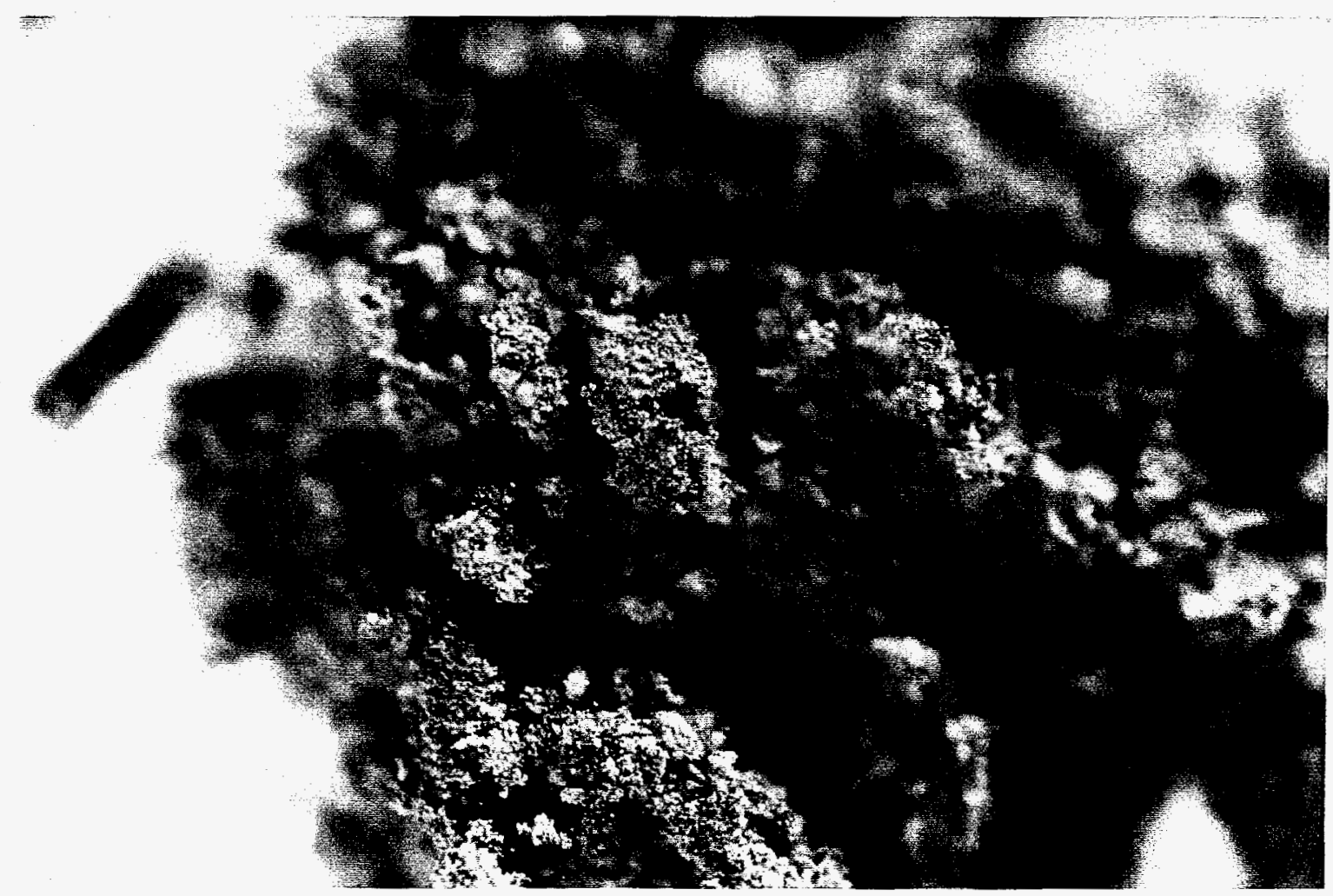

Figure 8. Horizontal probe ash (reddish area). 


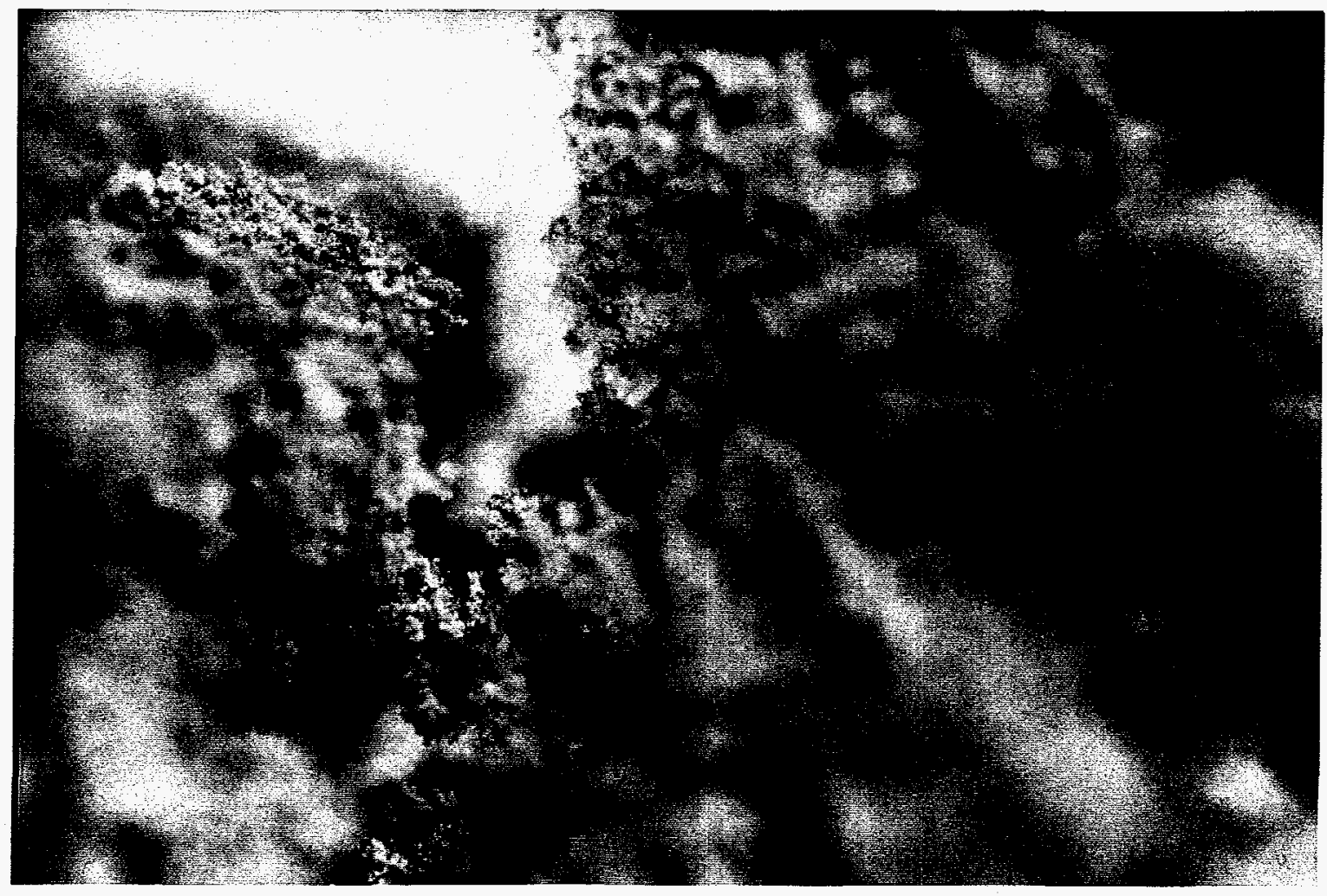

Figure 9. Horizontal probe ash (bottom area).

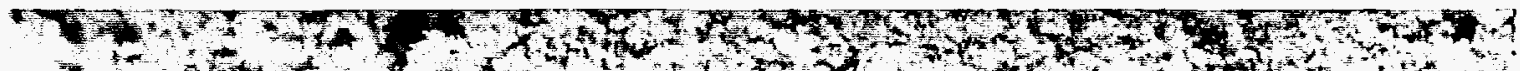

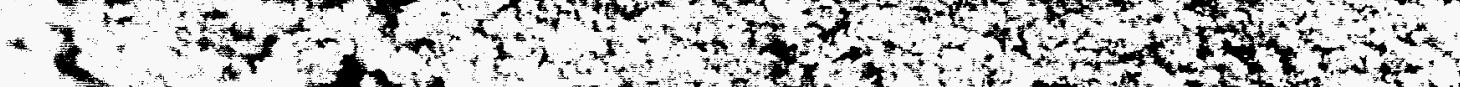

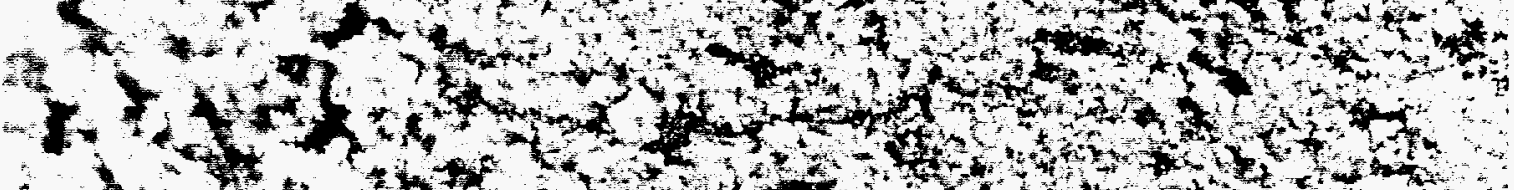

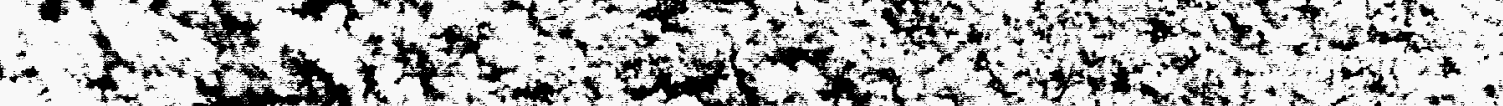

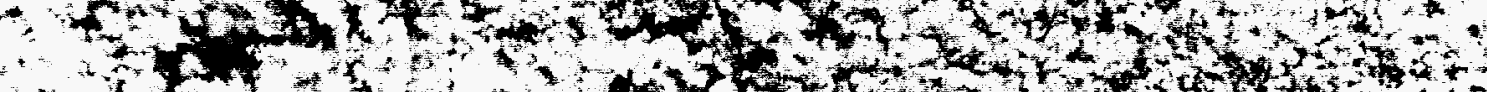

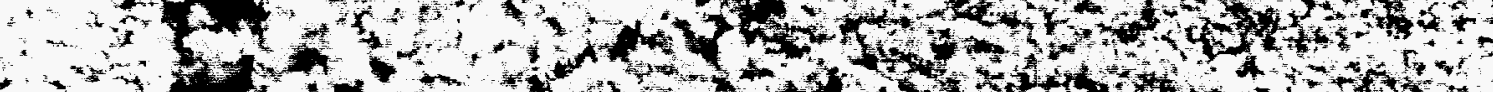

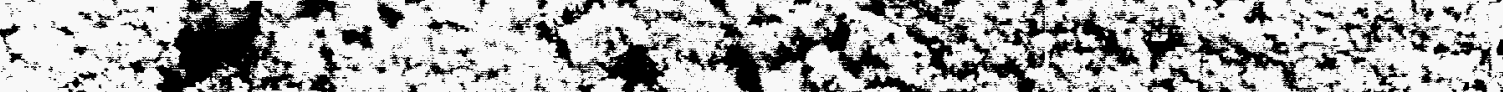

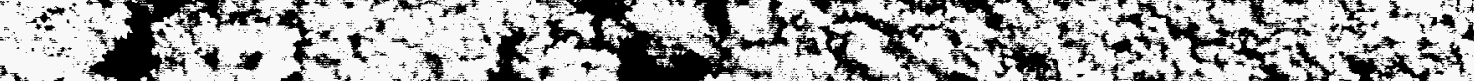

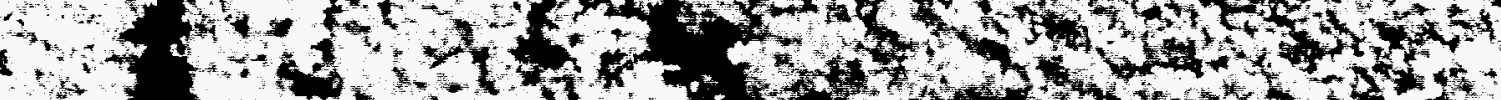

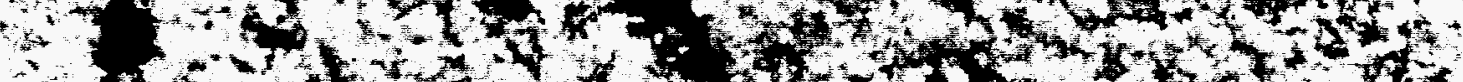

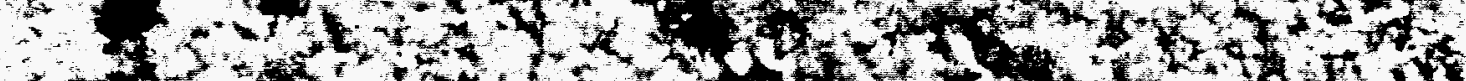

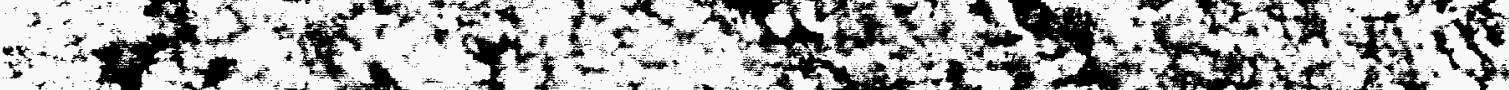

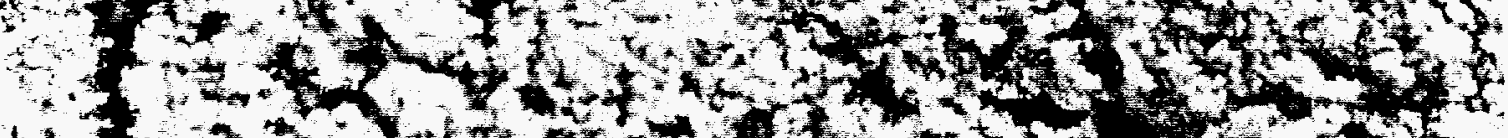
(1)

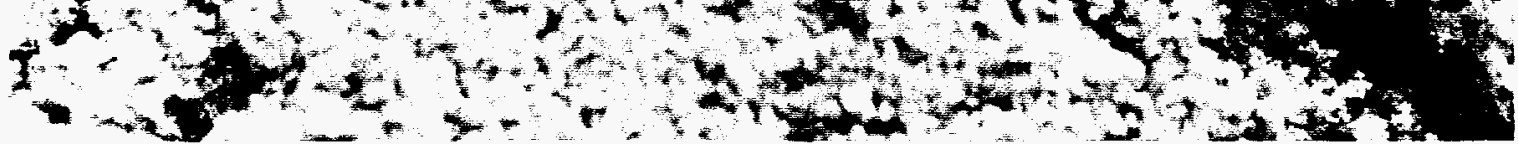

Figure 10. Horizontal probe ash (top area). 


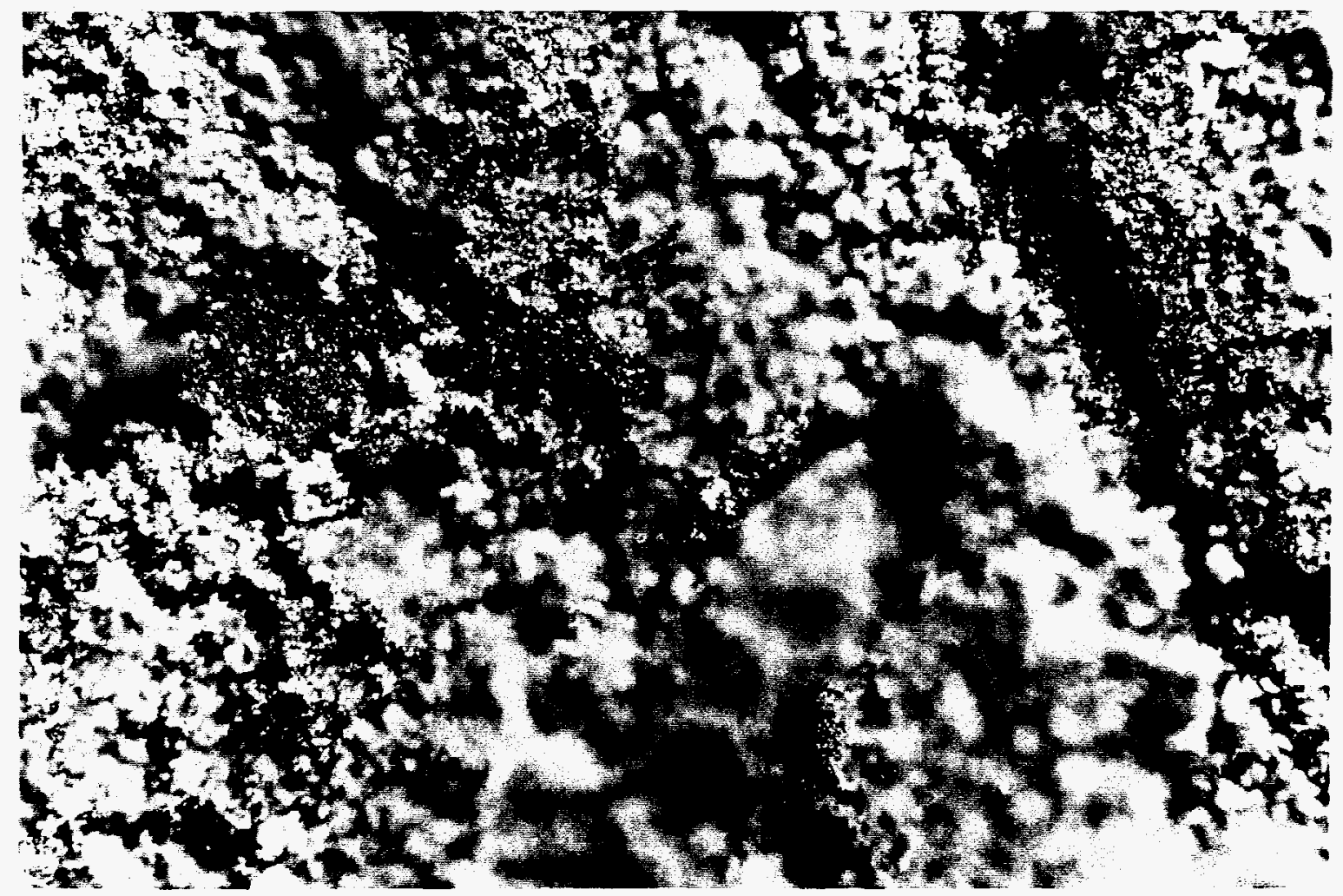

Figure 11. Wall probe ash.

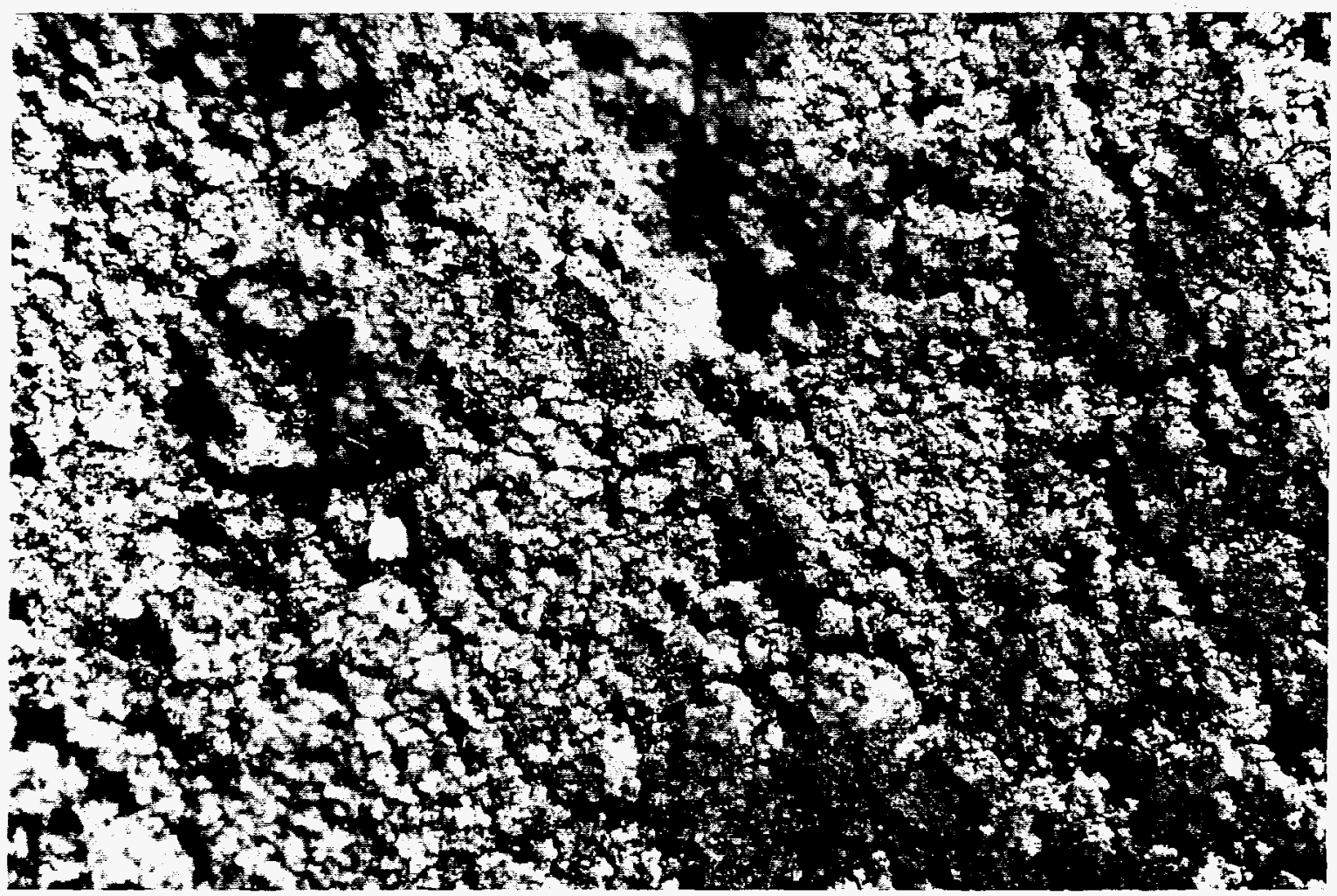

Figure 12. Air-cooled probe ash. 


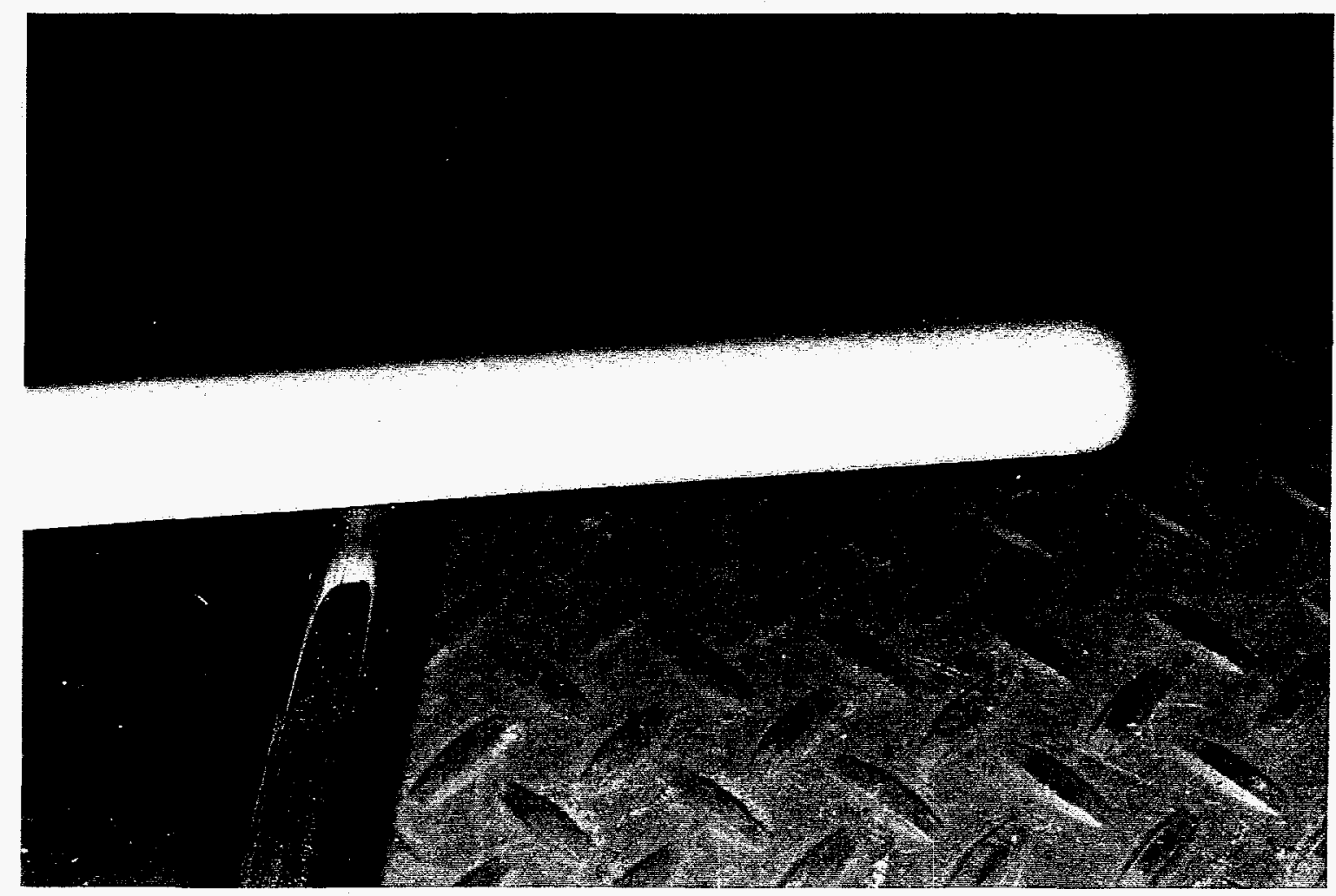

Figure 13. Mullite tube after $15 \mathrm{hr}$.

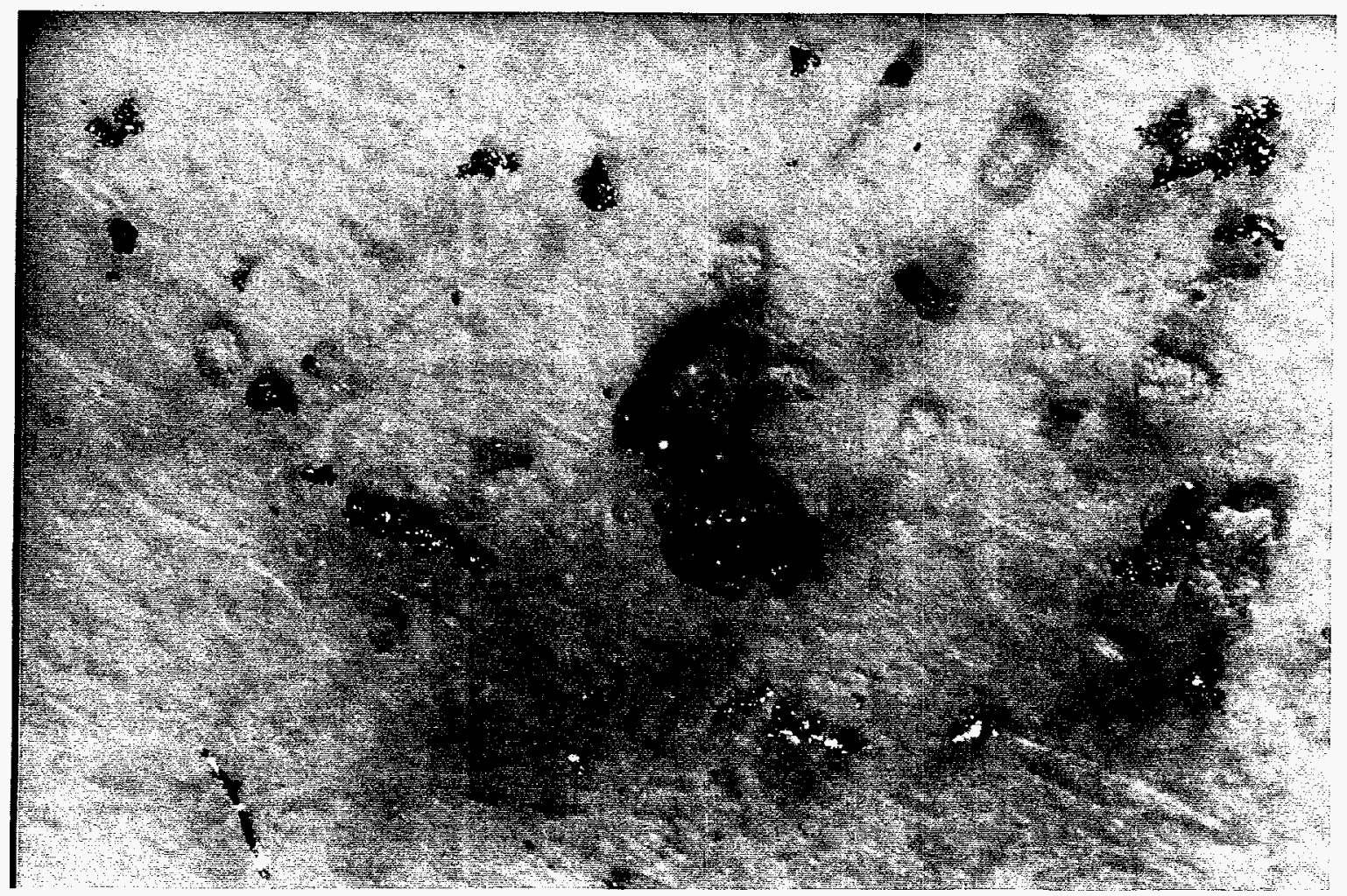

Figure 14. Mullite tube ash. 


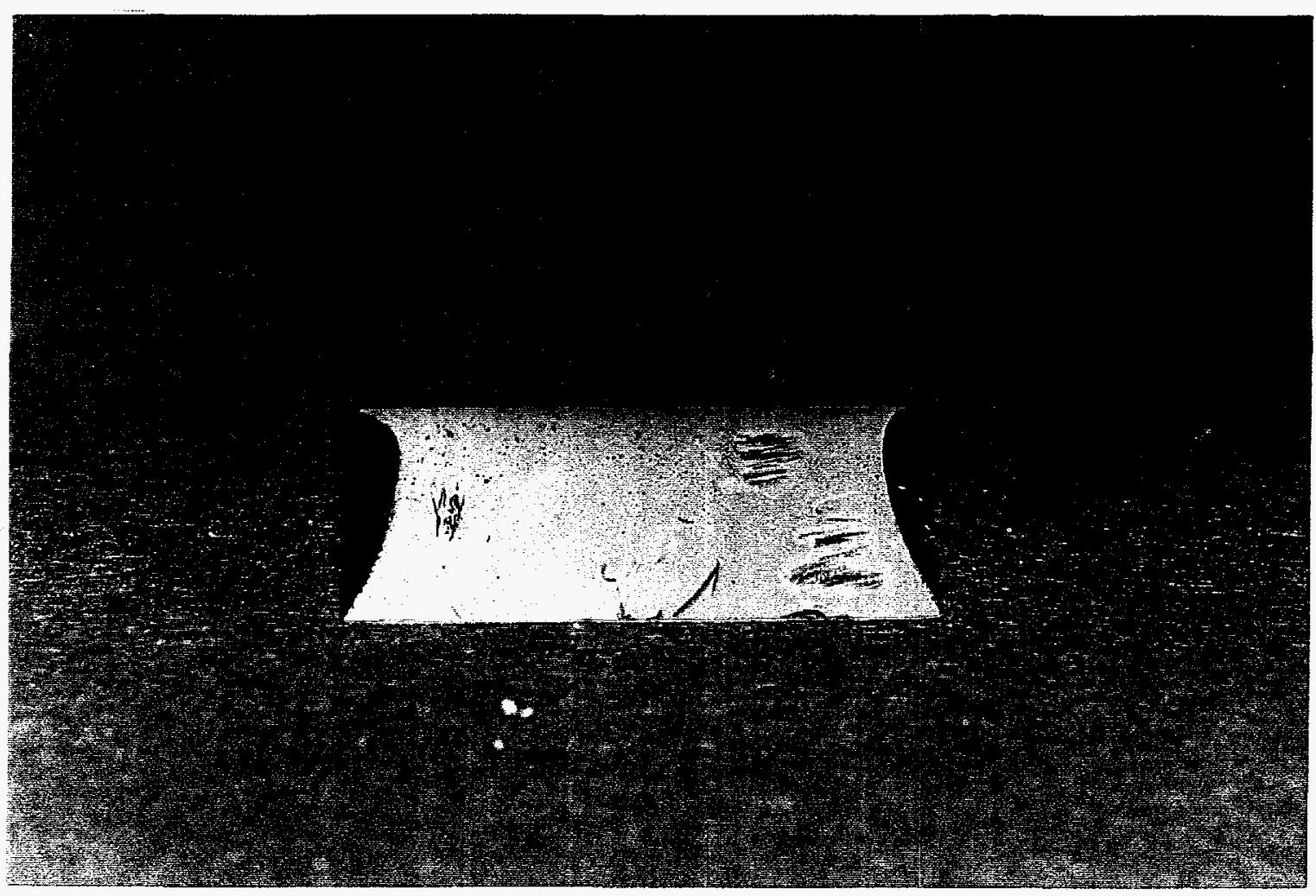

Figure 15. CEPS Run 33 coupon.

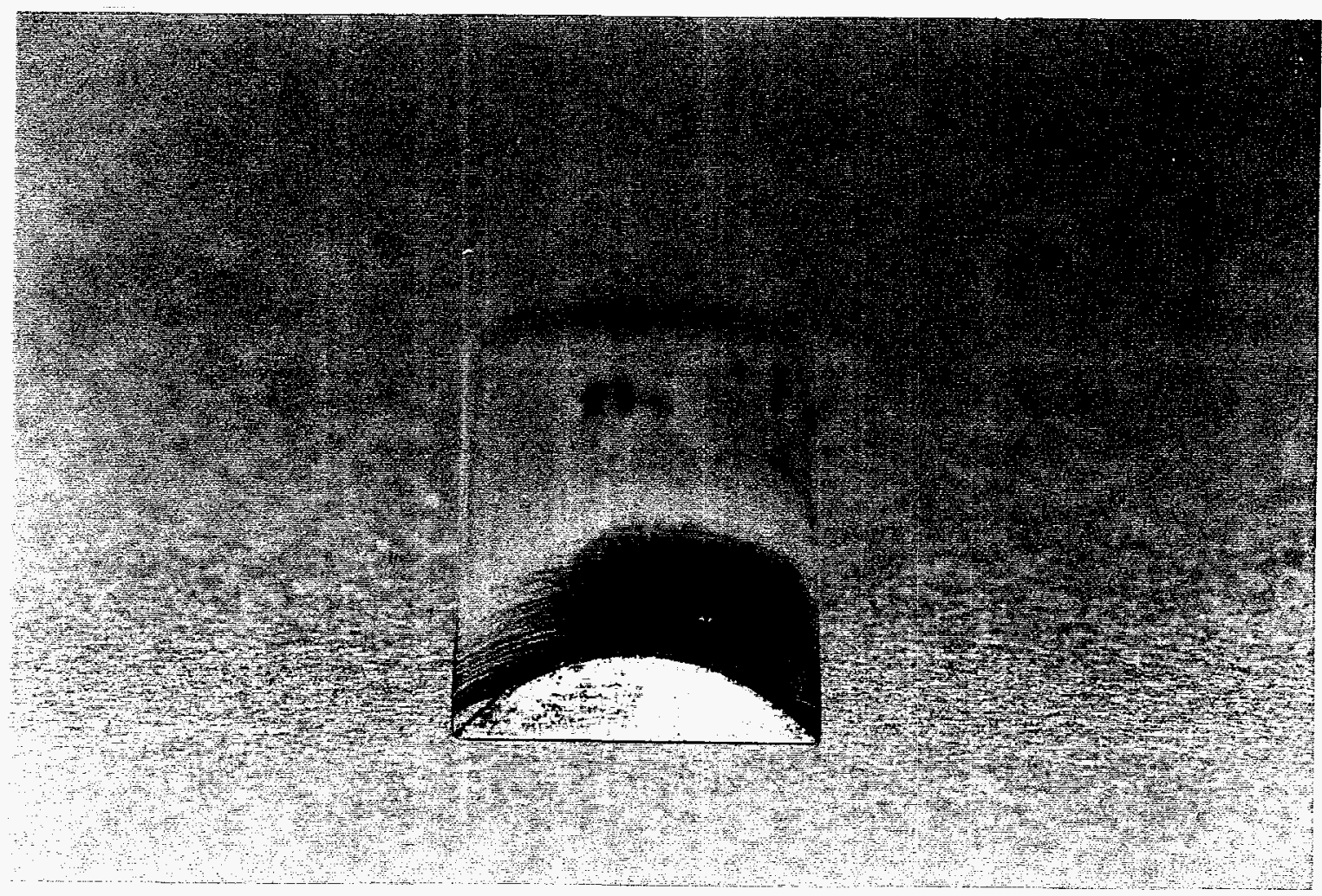

Figure 16. CEPS Run 33 coupon showing slag droplet in scraped area. 


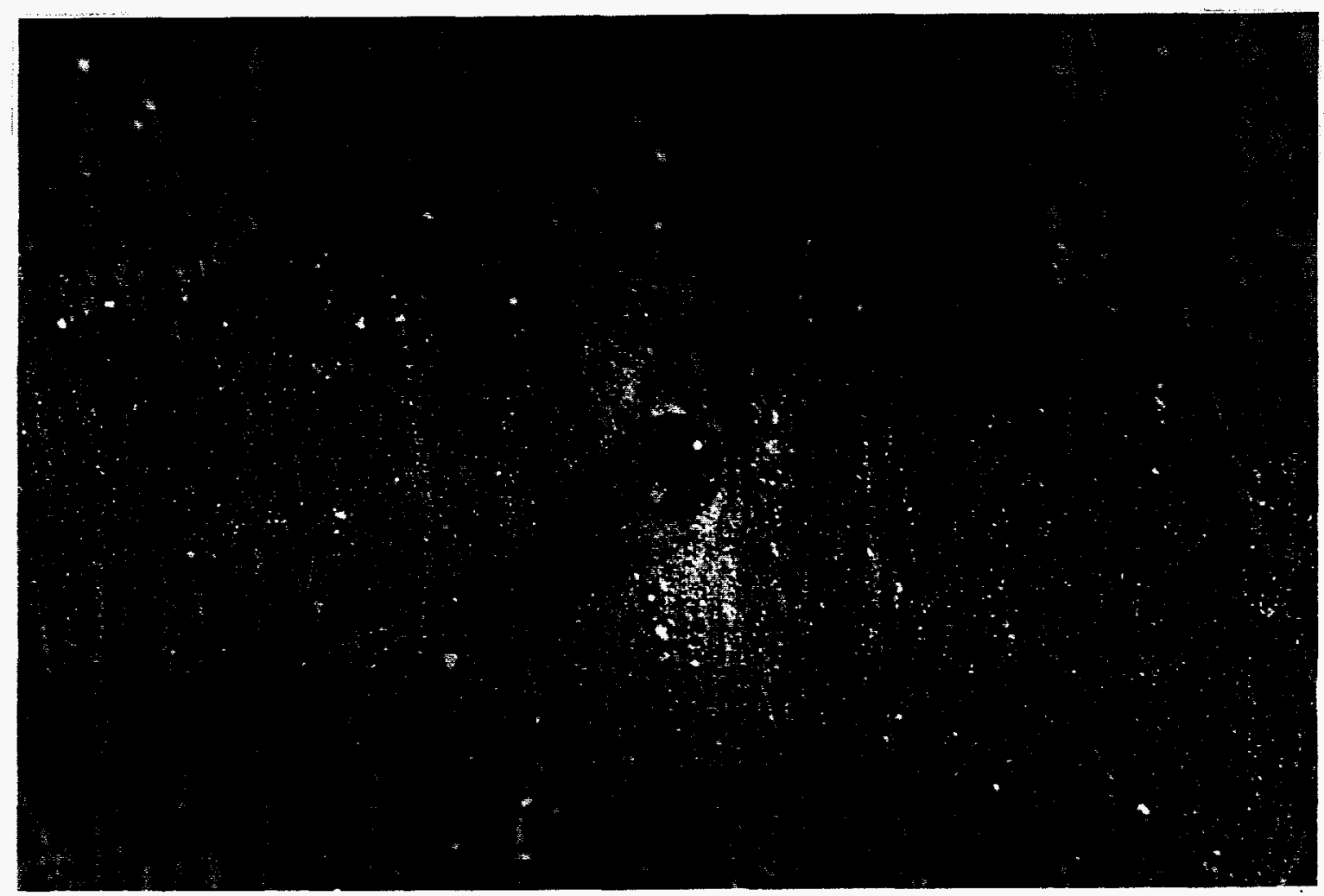

Figure 17. CEPS Run 33 slag droplet.

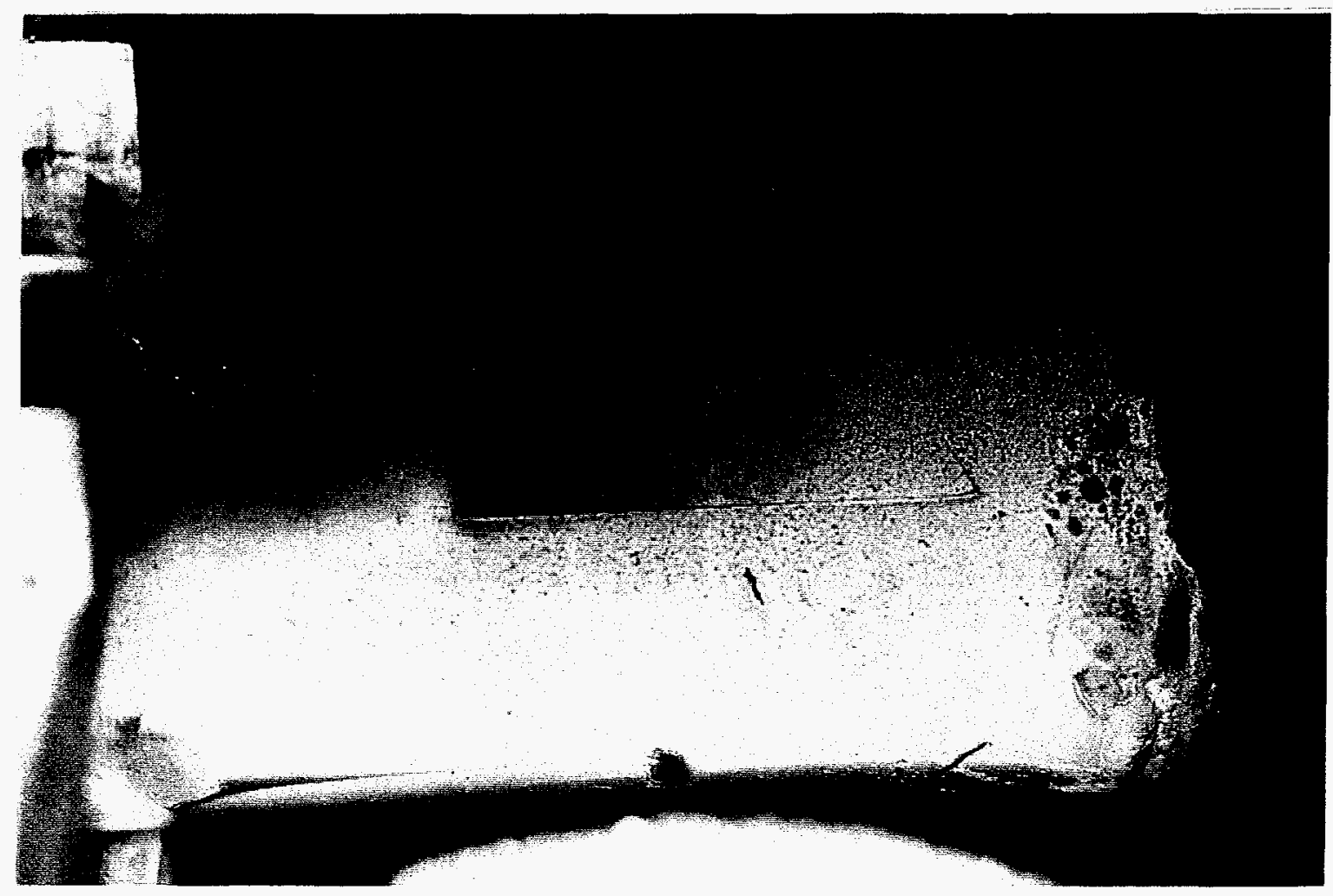

Figure 18. CEPS Run 34 deposit probe with coupon attached. 


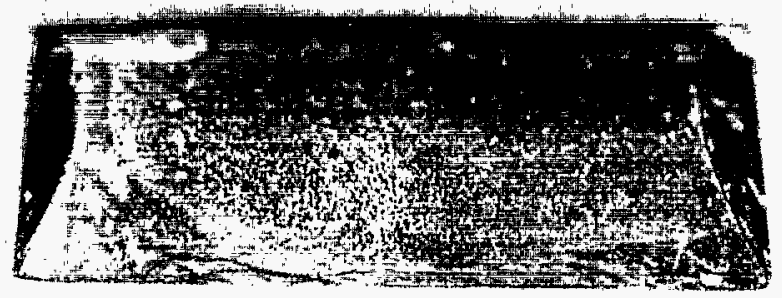

Figure 19. CEPS Run 34 coupon.

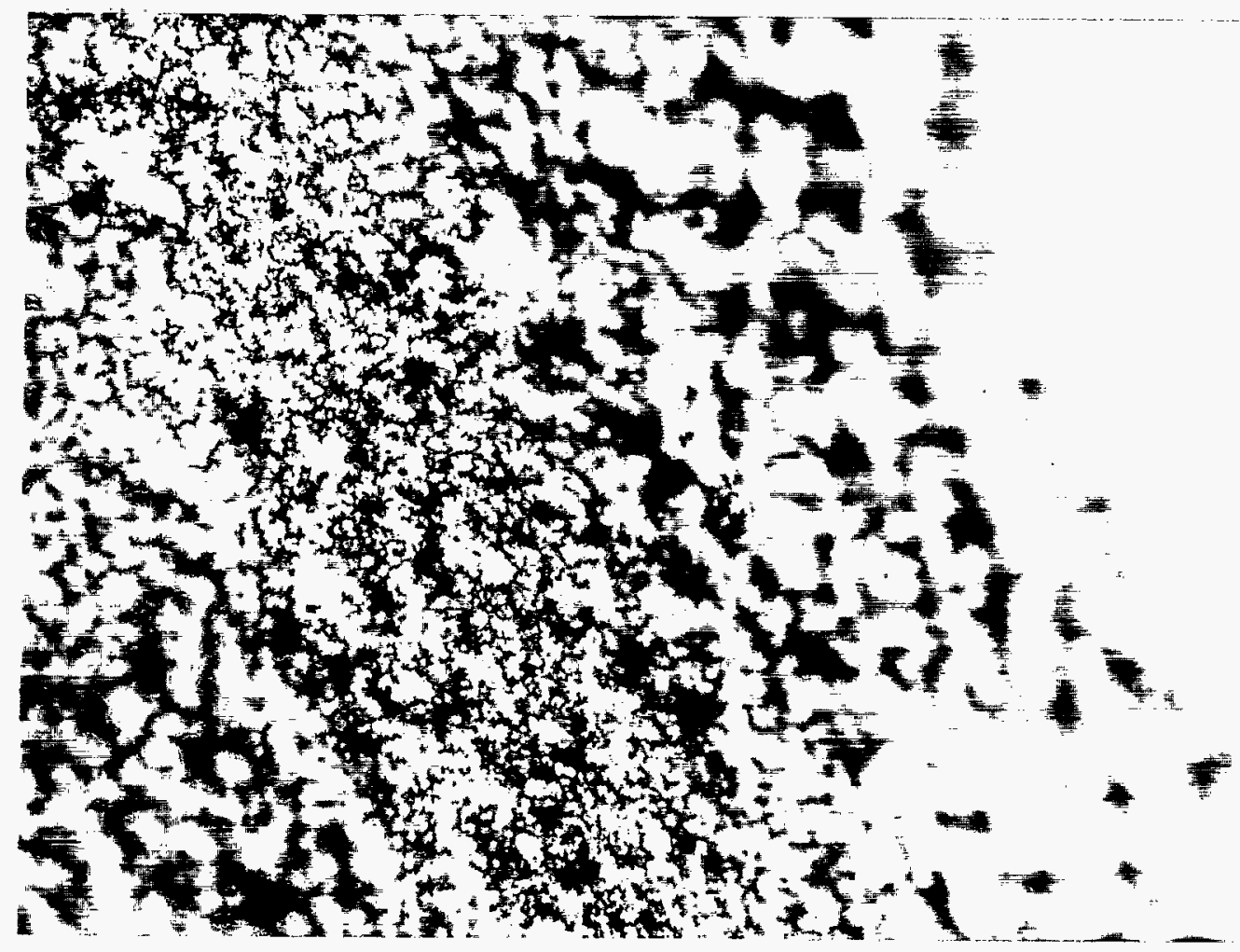

Figure 20. CEPS Run 34 ash. 
Run conditions for the 3-hr test (Run 33) and the 12-hr test (Run 34) are shown in Table 4. For each run, the fuel oil and air were fed at rates to achieve $0.5 \% \mathrm{O}_{2}$ in the flue gas. However, air leakage into the furnace caused the final $\mathrm{O}_{2}$ percentage to be higher, as shown. Photographs of the deposits were taken at the completion of the 3-and 12-hr test periods on the CEPS deposits. Deposit samples were also viewed under microscope inspection at a magnification of $70 \times$. Here there is greater evidence of slag formation than is visible with the naked eye. A set of photographs was obtained under a different microscope at a lower magnification. Figures 15-20 are selected pictures of the various deposits collected at the end of Runs 33 and 34.

TABLE 4

Run Conditions for CEPS Runs 33 and 34

\begin{tabular}{|c|c|c|}
\hline & CEPS Run 33 & CEPS Run 34 \\
\hline Primary Air, lpm & 27 & 27 \\
\hline Secondary Air, lpm & 83 & 83 \\
\hline Purge Air, lpm & 3 & 3 \\
\hline Atomizing Air, lpm & 7 & 7 \\
\hline Total Air In, lpm & 120 & 120 \\
\hline Estimated Air Leak In, lpm & 13.7 & 13.7 \\
\hline Fuel Rate, $\mathrm{lb} / \mathrm{hr}$ & 1.51 & 1.51 \\
\hline $\mathrm{O}_{2}, \%$ & 1.1 & 1.07 \\
\hline $\mathrm{CO}_{2}, \%$ & 15.19 & 15.76 \\
\hline $\mathrm{CO}, \%$ & $\mathrm{NA}^{*}$ & $\mathrm{NA}^{*}$ \\
\hline $\mathrm{SO}_{2}, \mathrm{ppm}$ & 632 & 642 \\
\hline $\mathrm{NO}_{\mathrm{x}}, \mathrm{ppm}$ & NA* & NA* \\
\hline \multicolumn{3}{|l|}{ Temperatures, ${ }^{\circ} \mathrm{C}$} \\
\hline Preheat Furnace & 1000 & 1000 \\
\hline Furnace 3 & 1500 & 1500 \\
\hline Furnace 4 & 1500 & 1500 \\
\hline Furnace 5 & 1450 & 1450 \\
\hline Furnace 6 & 1450 & 1450 \\
\hline Furnace 7 & 1200 & 1300 \\
\hline Preheat Air & 834 & 835 \\
\hline Secondary Air & 660 & 750 \\
\hline Section 2 & 1293 & 1376 \\
\hline Section 3 & 1402 & 1450 \\
\hline Section 4 & 1351 & 1381 \\
\hline Section 5 & 1354 & 1374 \\
\hline Section 6 & 1341 & 1375 \\
\hline Section 7 & NA** & $\mathrm{NA}^{* *}$ \\
\hline Section 8 & 570 & 729 \\
\hline Probe & 540 & $650 / 540$ \\
\hline
\end{tabular}

* Not available.

** Not available (deposit probe was installed in this temperature location). 


\subsection{RESULTS AND RECOMMENDATIONS}

Baseline testing of the RFO with $\mathrm{Mg}(\mathrm{OH})_{2}$ addition was performed in two separate test combustors of different scales. The first of these tests covered $15 \mathrm{hr}$ in the CTF. Two additional tests were performed in the CEPS combustor, the first covering a 3-hr duration and the second covering a 12-hr duration using higher furnace and probe metal temperatures. Results for each indicated similar deposit formation. Very small drops of slag were formed at the surface in each of these tests; however, the slag formation was not as dramatic over this time period as was expected. Microscopic examination of each deposit confirmed the onset of slag formation. Because significant slag formation (visible to the naked eye) was not achieved in the 15-hr test period on the CTF or the 12-hr test period on the CEPS, an alternative work plan was sought and all work was suspended so that FP\&L could review options.

Several options were considered to decrease the time or fuel required to form the baseline deposits. The first option was to run for an extended time period in the CTF (up to 48-hr durations), requiring additional fuel from FP\&L. The second option was to add additional ash to the RFO to increase its ash concentration from $0.08 \%$ to $1.0 \%$. A 5 -gal sample of ash was obtained from FP\&L's Riviera Plant dust collector and analyzed for this purpose. The results of these analyses are shown in Table 5 . This sample consisted of only $11.4 \%$ ash. To increase the ash

\section{TABLE 5}

FP\&L Riviera Plant Dust Collector Ash Analysis

\begin{tabular}{lcrr}
\hline Components, wt\% & 11.4 & & \\
Ash & 79.38 & & \\
Carbon & 0.87 & & \\
Nitrogen & 0.28 & & \\
Hydrogen & $\mathrm{A}$ & $\mathrm{B}$ & $\mathrm{C}$ \\
\hline Oxides, wt\% & 25.25 & 26.7 & 30.52 \\
$\mathrm{SiO}_{2}$ & 16.94 & 17.91 & 20.47 \\
$\mathrm{Al}_{2} \mathrm{O}_{3}$ & 8.18 & 8.65 & 9.89 \\
$\mathrm{Fe}_{2} \mathrm{O}_{3}$ & 0.86 & 0.91 & 1.04 \\
$\mathrm{TiO}_{2}$ & 0.73 & 0.77 & 0.88 \\
$\mathrm{P}_{2} \mathrm{O}_{5}$ & 0.87 & 0.92 & 1.05 \\
$\mathrm{CaO}$ & 8.22 & 8.69 & 9.93 \\
$\mathrm{MgO}$ & 1.66 & 1.76 & 2.01 \\
$\mathrm{Na}_{2} \mathrm{O}$ & 13.89 & 14.69 & 16.79 \\
$\mathrm{~V}_{2} \mathrm{O}_{5}$ & 6.11 & 6.46 & 7.38 \\
$\mathrm{NiO}_{\mathrm{K}} \mathrm{O}$ & 0.03 & 0.03 & 0.04 \\
$\mathrm{SO}$ & 11.83 & 12.51 & - \\
$\mathrm{Total}_{3}$ & 94.57 & 100 & 100 \\
\hline $\mathrm{A}=$ concentration, wt\% on an ash basis. & & \\
$\mathrm{B}=$ concentrations normalized to a closure of $100 \%$. & & \\
$\mathrm{C}=$ concentrations renormalized to a $\mathrm{SO}_{3}$-free basis. & &
\end{tabular}


concentration of the oil to $1.0 \%$, about $8 \mathrm{lb}$ of material was required per $100 \mathrm{lb}$ of oil. The third option was to perform the tests in the CEPS, which fires at a rate of less than $2 \mathrm{lb} / \mathrm{hr}$, for an extended time period.

It was determined that formation of the baseline deposit is essential to the overall success of the project and that testing of the additive would be meaningless in the absence of an established baseline. Because project resources (both fuel and funding) were limited, FP\&L requested that all project activities be suspended indefinitely.

To determine the effectiveness of zirconium as an additive for mitigation of the troublesome black glass, one or more of the recommendations below should be followed:

- Perform additional testing at the pilot scale over a test period of up to a 100 -hr duration to establish the baseline deposit.

- Addition of fly ash may be used to accelerate deposit growth.

- Perform a series of pilot-scale tests using the additive, with the same test duration as that established during baseline testing. Additive ratios of $1: 1,2: 1$, and $3: 1$ should be tested.

- Perform a series of additive tests similar to the above at full scale, collecting deposits over various time intervals to establish the long-term effects of using the additive.

In the absence of pilot-scale test results, caution should be used during full-scale testing of the additive to prevent an irreversible deposition event. 


\section{APPENDIX A}

\section{DESCRIPTION OF THE COMBUSTION TEST FACILITY (CTF) AND EXPERIMENTAL PROCEDURES FOR COAL-WATER FUEL COMBUSTION}




\section{COAL-WATER FUEL COMBUSTION DESCRIPTION OF FACILITIES AND PROCEDURES}

\section{BACKGROUND}

Research programs have been under way at the Energy \& Environmental Research Center (EERC) for more than 25 years to study fouling of boiler heat-transfer surfaces in coal-fired utility boilers. A $550,000 \mathrm{Btu} / \mathrm{hr}$ pulverized coal pilot plant test furnace was constructed in 1967 to evaluate the influence of variables, including ash composition, excess air, gas temperature, and tube wall temperatures, on ash fouling. Results from this work have shown a strong correlation between ash characteristics and degree of fouling.

The research capabilities of the EERC combustion test facility (CTF) have been enhanced and expanded to provide information on a wide range of combustion-related issues. The many research applications of this pilot-scale combustion equipment over the years have included:

- Determining ash-fouling rates and the strength, composition, and structure of fouling deposits

- Applying sophisticated analytical methods to characterize input coal, ash, and deposits and to correlate coal and ash properties with deposit growth rates and strength development

- Evaluating the effectiveness of ash-fouling additives

- Studying particulate-size distribution and velocity prior to deposition on convective section heattransfer surfaces

- Evaluating combustion characteristics of coal-water slurries

- Studying high-temperature baghouse operation and performance

- Evaluating sorbent injection for $\mathrm{SO}_{\mathrm{x}}$ control

- Assessing integrated particulate and $\mathrm{SO}_{\mathrm{x}} / \mathrm{NO}_{\mathrm{x}}$ control

- Studying $\mathrm{NO}_{\mathrm{x}}$ control using selective catalytic reduction and disposable catalysts

- Evaluating ash slagging potential in a simulated wet-bottom firing mode

- Performing flame stability tests for comparing a particular fuel at full load and under turndown conditions

\section{COMBUSTION TEST FACILITY}

An isometric drawing of the EERC combustion test facility (CTF) is shown in Figure A-1. The furnace capacity is approximately $700,000 \mathrm{Btu} / \mathrm{hr}$ of slurry fuel firing at a rate between 95 and $115 \mathrm{lb}$ of slurry fuel $/ \mathrm{hr}$. The combustion chamber is 30 inches in diameter, 8 feet high, and refractory-lined. 
Although designed as a pulverized coal-fired unit with more than 700 combustion tests completed to date, more than 200 combustion tests firing slurry fuels have been performed on coals of varying rank.

When slurry fuels are fired, the bottom of the combustion chamber is replaced to accommodate a burner with adjustable, secondary air swirl vanes. The slurry is pumped from a continuously stirred storage tank through the burner gun to the atomizer, where it mixes with atomizing air prior to entering the burner throat (see Figure A-2). A schematic of the atomizer used during combustion of slurry fuel is presented in Figure A-3. Heated primary air carries the atomized slurry out of the burner gun, while heated secondary air is introduced in an annular section surrounding the burner gun. Heated tertiary air is added through two tangential ports located in the furnace wall about 1 foot above the burner cone. The percentages of the total air used as primary, secondary, and tertiary air are usually 10, 65, and 25 , respectively. Flue gas passes out of the furnace into a 10 -inch-square duct that is also refractory-lined. Located in the duct is a vertical probe bank designed to simulate superheater surfaces in the convective pass of a utility boiler.

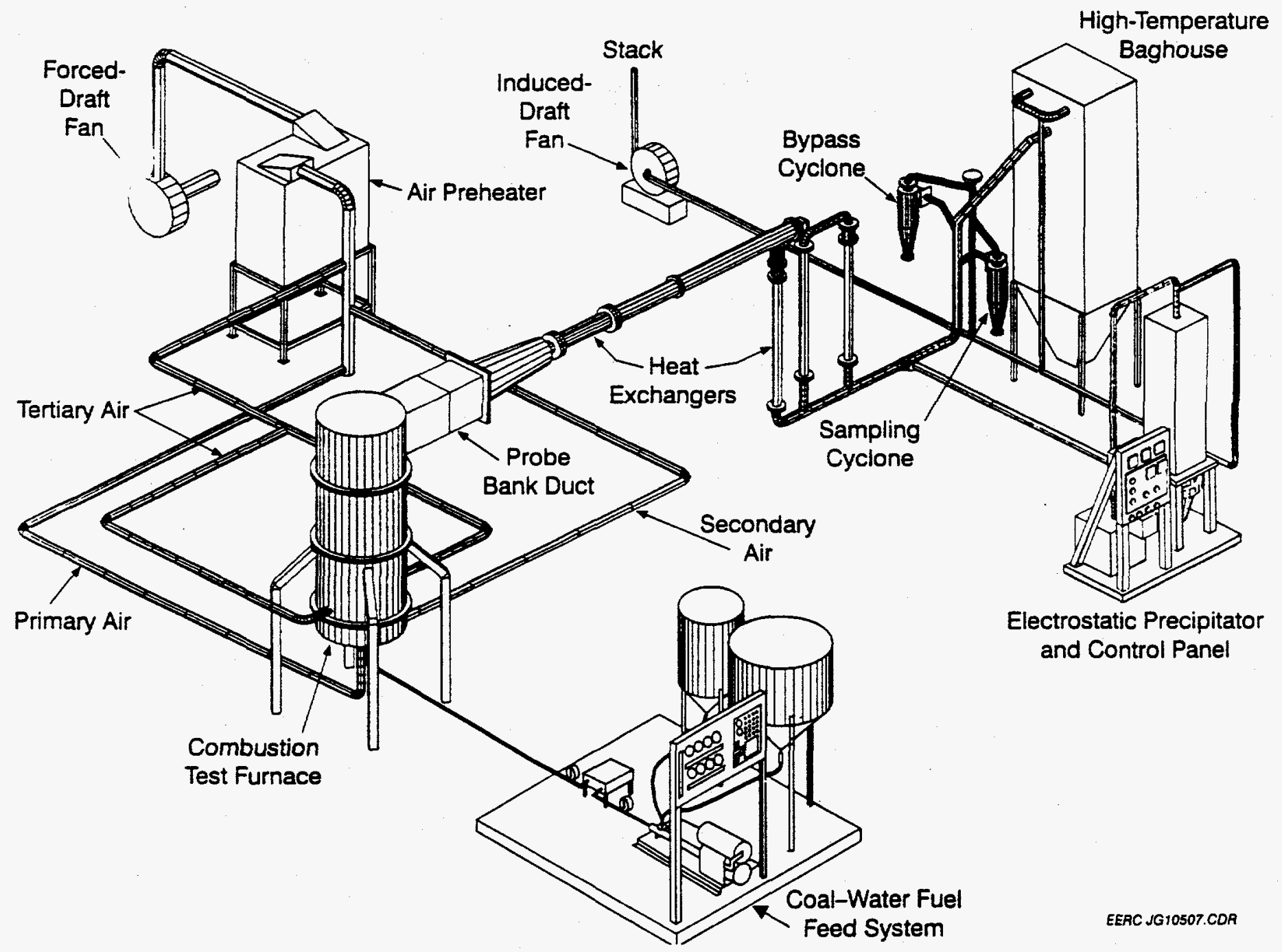

Figure A-1. Slurry-fired test combustor and auxiliary systems. 


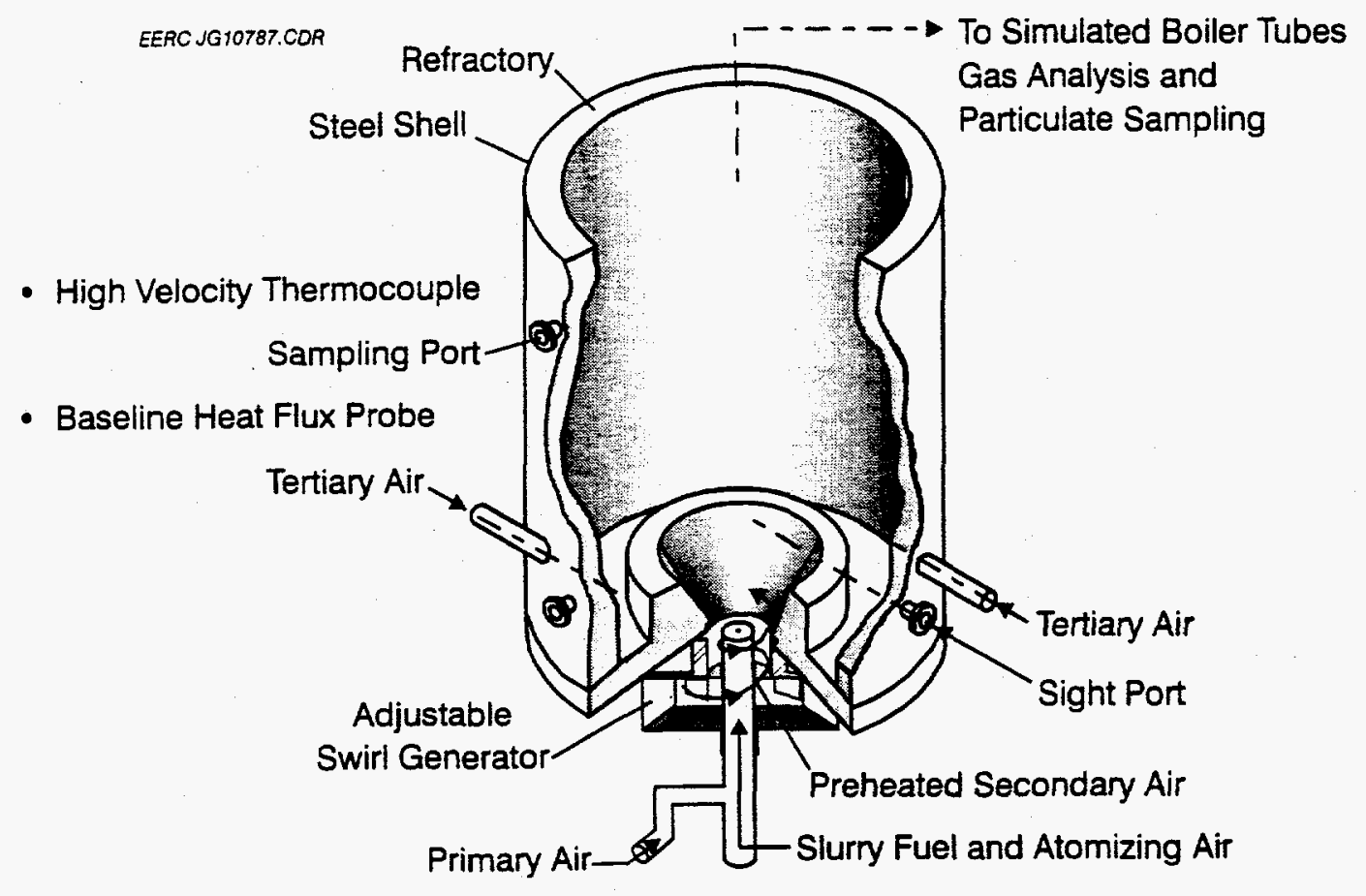

Figure A-2. Schematic of combustion test furnace.

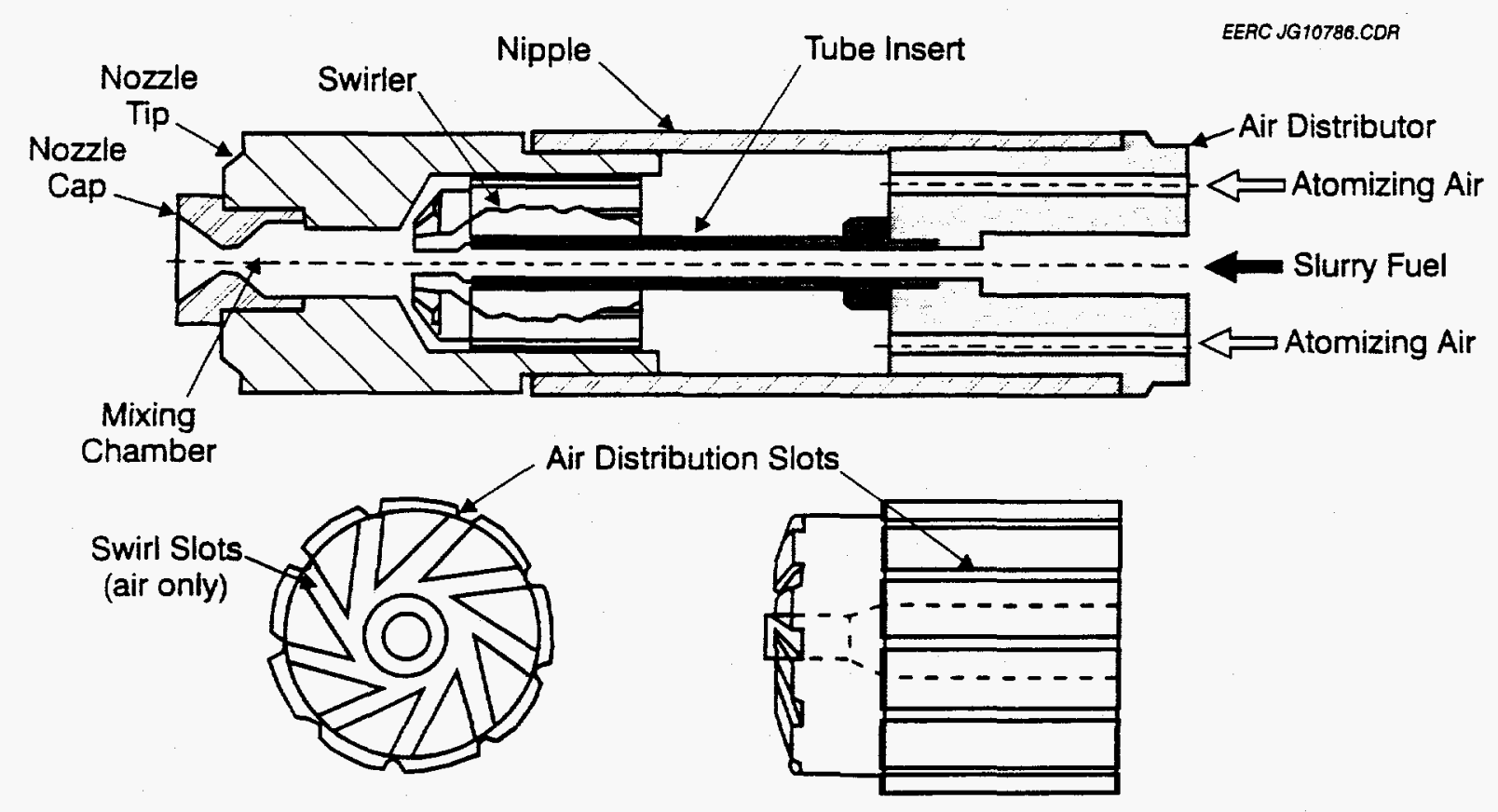

Figure A-3. BII atomizer used during combustion testing of slurry fuel. 
The furnace is fired at a rate sufficient to maintain the furnace exit gas temperature at a constant level (usually $2000^{\circ} \mathrm{F}$ or $2200^{\circ} \mathrm{F}$ ), with excess air maintained at a specified level (usually $20 \%$ or $25 \%$ excess air). The slurry fuel feed rate and air flow rates are adjusted accordingly to maintain these operating conditions. Upon leaving the probe bank duct, the flue gas passes through a series of watercooled heat exchangers used to control the temperature entering the particulate control device (either an electrostatic precipitator [ESP] or a pulse-jet baghouse). The ESP is operated at a constant inlet gas temperature (usually specified between $300^{\circ}$ and $350^{\circ} \mathrm{F}$ ) with voltage input regulated to the highest voltage attainable without sparkover or back-corona effects (usually about $60 \mathrm{kV}$ ). ESP performance is characterized by obtaining a series of U.S. Environmental Protection Agency (EPA) Method 5 particulate samples at both the ESP inlet and outlet. The fly ash collected by the ESP is subjected to a laboratory determination of resistivity in addition to standard American Society for Testing and Materials (ASTM) analyses and advanced scanning electron microscope (SEM) analyses.

In addition to the fouling probe bank at the furnace exit, the test furnace contains numerous ports through which gas and fly ash samples may be collected, and various probes may be inserted for collection of deposits. Standard ASTM techniques and advanced laboratory and SEM techniques are utilized to analyze the various samples collected.

Figure A-4 shows the construction of the ash-fouling test probe bank, which is located in a hinged door to facilitate inspection and cleaning. The three fouling probes are constructed of 1.66-inch-OD, Type 304 stainless steel pipe and are cooled with compressed air. Each probe has two thermocouples embedded in its upstream edge to measure metal temperature. One of the thermocouples on each probe is attached to a temperature recorder/controller that regulates the cooling air to the probe. Normally, the surface temperature of each probe is maintained at $1000^{\circ} \mathrm{F}$, while the gas temperature entering the probe bank is maintained at approximately $2000^{\circ} \mathrm{F}$. When the furnace is fired in the bituminous mode, the temperature entering the probe bank has been as high as $2400^{\circ} \mathrm{F}$. The gas velocity between the tubes is normally about $25 \mathrm{ft} / \mathrm{s}$ when low-rank coals are fired.

After leaving the probe bank duct, the flue gas passes through a series of water-cooled heat exchangers before being discharged through either an ESP or a baghouse. An ESP is normally used for collection of fly ash during standard combustion tests.

\section{General Test Method}

The relative fouling potential and other tendencies of test coals are determined by burning coal samples under specified conditions. When starting with a cold furnace, the following 13.25-hour test program is normally used:

$\begin{array}{lr} & \text { Hours } \\ \text { Preheat on gas } & 8.00 \\ 100 \% \text { slurry fuel firing } & \underline{5.25} \\ \text { Total } & 13.25\end{array}$

The slurry fuel feed rate is commonly adjusted to keep the flue gas temperature entering the upper duct to the probe bank at $2000^{\circ} \mathrm{F}$ with $25 \%$ excess air. Slurry samples are taken periodically to form a composite sample. Oxygen, carbon dioxide, nitrous oxides, carbon monoxide, and sulfur dioxide in the flue gas are continuously monitored by recording analyzers. 


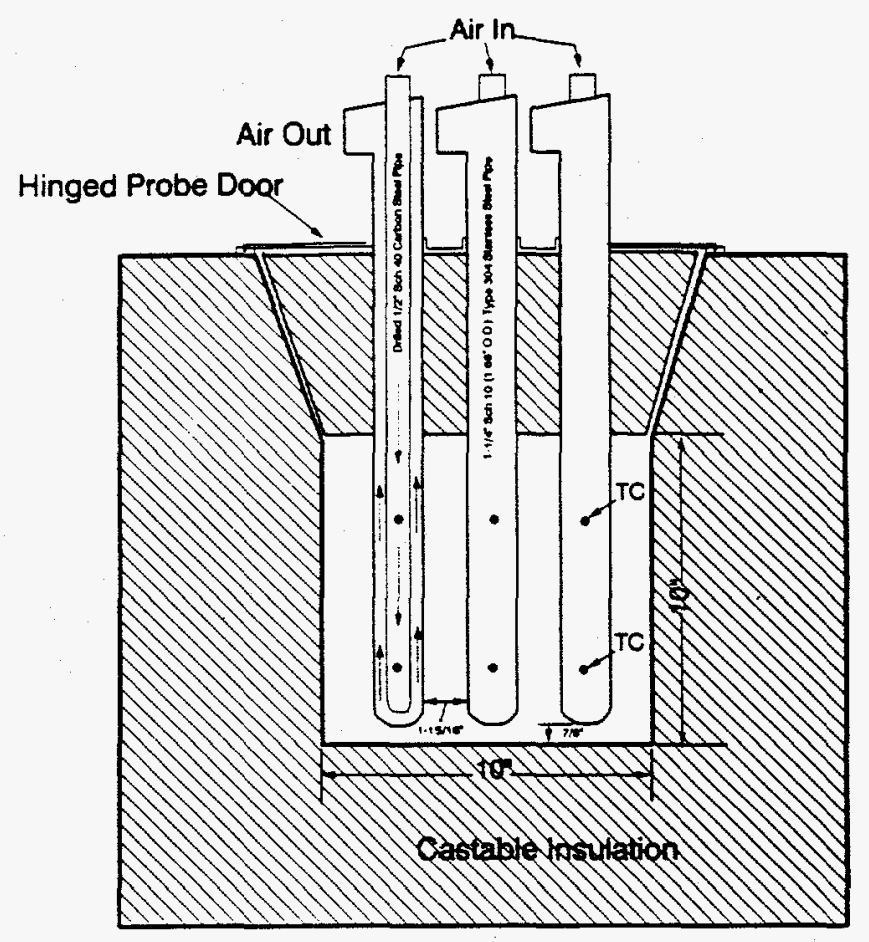

Figure A-4. Detail of probe bank construction.

The operating conditions and procedures described above are those normally utilized in studying the ash-fouling tendencies of low-rank western coals. They are included for the purposes of reference and description, and for comparison with the conditions actually utilized when burning slurry fuel.

The test furnace has numerous ports that permit observation of the probes and the furnace burner zone during the test run. These ports can also be used for installation of additional test probes, auxiliary measurements, photography of probes, or injection of additives.

At the completion of the test period, the probe door is carefully opened and photographs are taken of the deposit. The deposit is then removed from the probes in two fractions, an inner and an outer layer, and each is weighed and analyzed separately. Normally the inner white layer weighs less than 10 grams, as compared to 100 to 500 grams for the outer sintered deposit.

The weight of ash deposited on the probe bank during a standard test is used to rank the coal for its relative fouling potential. To ensure that the pilot-scale test results are meaningful for evaluation of ash-fouling potential in full-scale utility boilers, calibration tests were previously conducted with low-rank coals known to produce low and high fouling in utility boilers. Comparisons of ash fouling have been made based on tests conducted at a number of power stations throughout the western United States: Monticello (Texas Utilities), Big Brown (Texas Utilities), Four Corners (Arizona Public Service Company), St. Clair (Detroit Edison Company), Jim Bridger (Pacific Power and Light), Big Stone (Otter Tail Power Company), Leland Olds (Basin Electric Power Cooperative), and San Miguel (San Miguel Electric Cooperative). Based on these tests, the ash deposit buildup rate on the probe bank was found 
to be a good indicator of fouling potential. The relationship between deposit weight and a fuel's fouling potential is generally categorized as indicated below:

$\begin{array}{cc}\text { Deposit Weight, grams } & \text { Relative Fouling Potential } \\ 0-150 & \text { Low } \\ 150-300 & \text { Medium } \\ \text { Above } 300 & \text { High }\end{array}$

\section{Deposit Strength Tests}

The weight of the ash deposit from the probe bank has proven to be a good indicator of the fouling potential for most coals tested in the this furnace. Heavy deposits in the 5.25-hour test indicate high deposition rates, which can usually be related to potential ash-fouling problems in utility boilers. However, the deposition rate does not provide an indication of the ease of deposit removal by sootblowing. Methods to measure deposit tenacity and strength have been reviewed at the EERC, and strength test methods have been developed that appear to provide reliable, reproducible results.

Deposit strength is initially assessed by means of the strength rating factor (SRF). This factor is determined based on observations made by a pilot-plant operator during removal of ash deposits from the probe bank. Deposit hardness and breakability is rated from 1 to 10 , with 1 indicating soft and crumbly and 10 indicating hard and unfragmented.

The probe deposit is also subjected to a laboratory deposit strength evaluation procedure developed at the EERC, which utilized a drop impactor technique. A known weight is dropped with a measured impact on the sliced face of a 1-inch-long deposit sample. After the drop test, the sample is sieved in a sonic sifter through a series of six screens ranging in size from 5.66 to $0.21 \mathrm{~mm}$. The percentage of each size is determined and, using the procedure from the ASTM Tumbler Test (ASTM Method D44145), the dust index, friability, and mass mean diameter of the crushed deposit sample are determined. An impact resistance value (IRV) is calculated, which adjusts the results of the impactor tests for the test parameters under which they were obtained. The calculation was developed by analysis of a large body of data obtained by this procedure.

\section{Flame Stability Testing}

\section{Background}

Flame stability is assessed by observation of the flame and its relation to the burner quarl as a function of secondary air swirl and operating conditions at full load and under turndown conditions. An International Flame Research Foundation (IFRF)-type adjustable secondary air swirl generator (shown in Figure 3) uses primary and secondary air at approximately $15 \%$ and $85 \%$ of the total air, respectively, to adjust swirl between 0 and a maximum of 1.9. Swirl is defined as the ratio of the radial (tangential) momentum to axial momentum imparted to the secondary air by movable blocks internal to the burner and is used to set up an internal recirculation zone (IRZ) within the flame that allows greater mixing of combustion air and coal. Swirl is imparted by moving these blocks to set up alternate paths of radial flow and tangential flow, creating a spin on the secondary air stream that increases the turbulence in the nearburner zone. At the fully open position of the swirl block, the secondary air passes through the swirl 
burner unaffected and the momentum of this stream has only an axial component (the air enters the combustion chamber as a jet). As the angle of the blocks changes, the air begins to spin or "swirl" and the radial component to the momentum is established, creating the IRZ in the near burner region. It is the ratio of this radial component of the momentum to the axial component that establishes the quantity defined as "swirl".

The adjustable swirl burner used by the EERC during flame stability testing consists of two annular plates and two series of interlocking wedge-shaped blocks, each attached to one of the plates. The two sets of blocks can form alternate radial and tangential flow channels, such that the air flow splits into an equal number of radial and tangential streams which combine further downstream into one swirling flow as shown in Figure 4. By simply rotating the movable plate, radial channels are progressively closed and tangential channels opened so that the resulting flux of angular momentum increases continuously, between zero and a maximum value. This maximum swirl depends on the total air flow rate and the geometry of the swirl generator. Swirl can be calculated based on dimensions of the movable blocks (the ratio of the tangential and radial openings of the blocks) or based on the measurement of the velocity of the air stream (obtaining both radial and axial components). The following description of that calculation is provided by Beer and Chigier (3).

When rotating motion is imparted to a fluid upstream of an orifice, the fluid flow emerging from the orifice has a tangential velocity component in addition to the axial and radial components of velocity encountered in non-swirling jets. The presence of the swirl results in the setting up of radial and axial pressure gradients which, in turn, influence the flow field. In the case of strong swirl, the adverse axial pressure gradient is sufficiently large to result in reverse flow along the axis, setting up the internal recirculation zone.

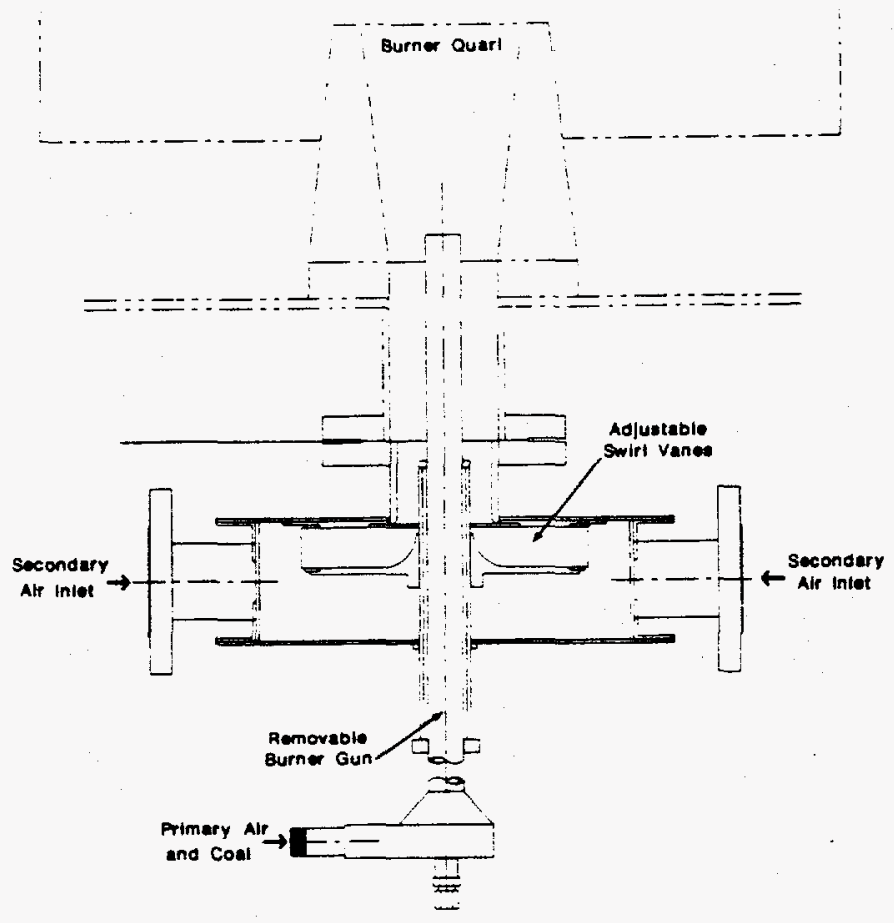

Figure A-5. IFRF adjustable swirl burner. 


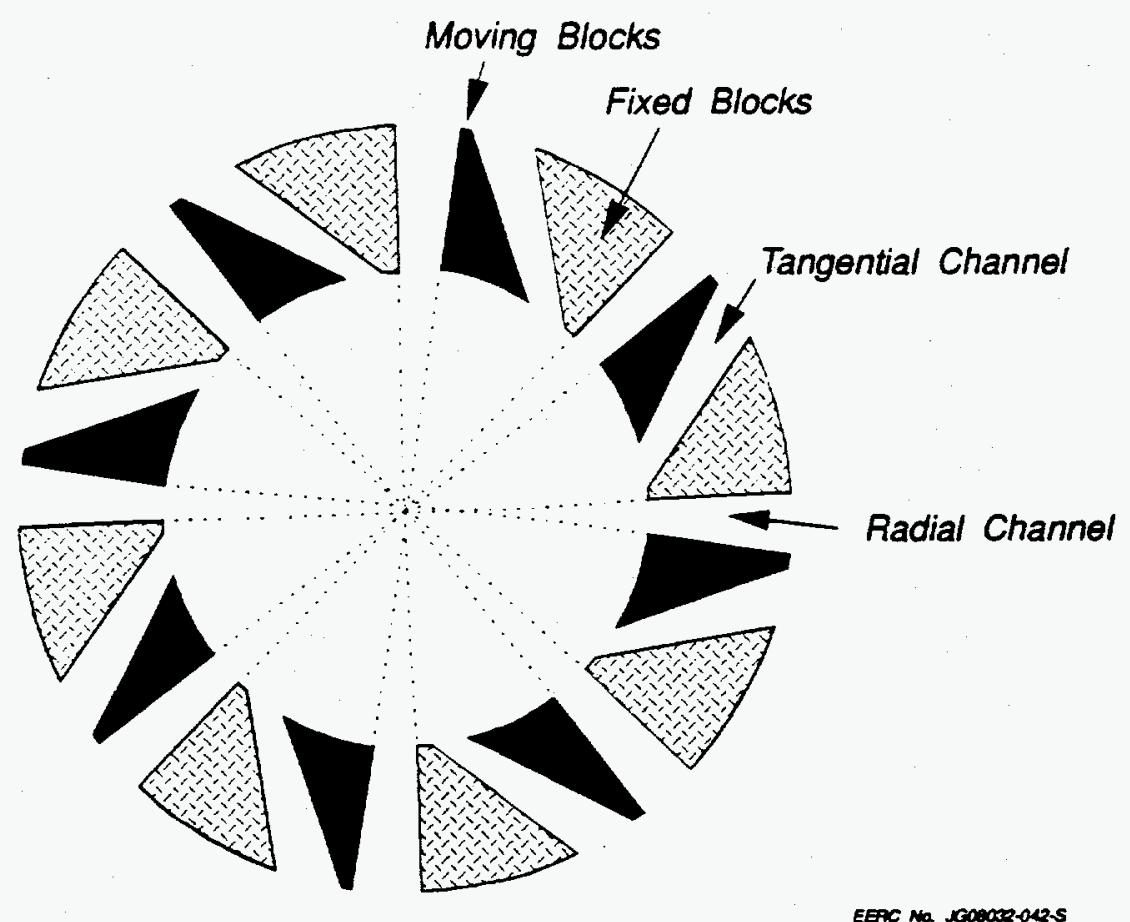

Figure A-6. Cross-section of movable block assembly.

In swirling free jets or flames, both axial flux of the angular momentum $\left(G_{\varphi}\right)$ and the axial thrust $\left(G_{x}\right)$ are conserved. These can be written as

$$
\begin{gathered}
\mathrm{G}_{\varphi}={ }_{0} \int^{\mathrm{R}}[(W r) \rho U 2 \pi \mathrm{r}] \mathrm{dr}=\mathrm{const} \\
\mathrm{G}_{\mathrm{x}}={ }_{0} \int^{\mathrm{R}}\left[U_{\rho} U 2 \pi \mathrm{r}\right] \mathrm{dr}+{ }_{0} \int^{\mathrm{R}}[\mathrm{p} 2 \pi \mathrm{r}] \mathrm{dr}=\mathrm{const}
\end{gathered}
$$

where, $U, W$ and $\mathrm{p}$ are the axial and tangential components of the velocity and static pressure, respectively, in any cross section of the jet. Since both these momentum fluxes can be considered to be characteristic of the aerodynamic behaviour of the flame, a non-dimensional criterion based on these quantities can describe the swirl intensity as

$$
S=G_{\psi} / G_{x} R \quad(R=\text { exit radius of the burner nozzle }) .
$$

Experiments have shown that the swirl number $S$ was the significant similarity criterion of swirling jets produced by geometrically similar swirl generators. Other similarity criteria which take account of non-isothermal conditions and of confinement of jet flow by walls can also be applied in conjunction with the swirl number. The calculation of swirl in other types of swirl generators such as the air registers on a utility boiler are also described by Beer and Chigier (3), though not mentioned here. 
Secondary air swirl is used to stabilize the flame. In the absence of swirl, loss of flame may result, increasing the risk of dust explosion. As swirl is applied to the combustion air, coal particles are entrained in the IRZ, increasing the heating rate of the particles, leading to increased release of volatiles and char combustion. The flame becomes more compact and intense as swirl is increased to an "optimum" level, which is characterized in EERC's test facility as the point at which the flame makes contact with the burner quarl. Increasing swirl beyond this level can pull the flame into the burner region, unnecessarily exposing metal burner components to the intense heat of the flame and possible combustion in the coal pipe.

Increasing swirl to provide flame stability and increased carbon conversion can also affect the formation of $\mathrm{NO}_{x}$. The high flame temperatures and increased coal/air mixing associated with increased swirl create an ideal situation under which $\mathrm{NO}_{\mathrm{x}}$ may form. In full-scale burners with adjustable vanes, swirl is often increased to reach the "optimum" condition and then decreased slightly to reduce the production of $\mathrm{NO}_{\mathbf{x}}$.

\section{General Test Method}

The general test method sets the burner at its maximum level of swirl and monitors system parameters such as fuel feed rate, excess air, gaseous emissions $\left(\mathrm{CO}_{2}, \mathrm{CO}, \mathrm{SO}_{x}\right.$, and $\left.\mathrm{NO}_{x}\right)$, combustor static, and air flow rates. Photographs of the flame and burner zone are then taken through a sight port in the furnace proper just above the burner cone using standard $35-\mathrm{mm}$ film. Flame temperature is also measured using a high-velocity thermocouple (HVT) at a set location in the furnace, and heat flux is monitored using a baseline heat flux probe at the same location. An ash sample is also collected at each swirl setting to establish carbon burnout. The swirl setting is then reduced until the flame is visually observed to lift off the burner quarl. At this point, the flame is characterized as unstable under full load conditions (between 600,000 and $650,000 \mathrm{Btu} / \mathrm{hr}$ firing rate). Photographs are again taken to record the flame at this setting, temperature and heat flux measurements are taken, and an ash sample is taken once again. Having established flame liftoff, the optimum swirl setting is then located by visual observation of the flame, and measurements are recorded once again.

Flame stability under turndown conditions is characterized by firing the test fuel at reduced load (typically one-half to three-quarter the full load rate), maintaining the same primary air flow and adjusting the secondary air flow to meet excess air requirements. The procedure described above is then used to establish flame stability at reduced load.

\section{Furnace Wall Slag Probes}

The combustion test facility (CTF) at EERC was originally designed for tests of fouling potential of low-rank coals. As a result, the nominal design values of heat input $(550,000 \mathrm{Btu} / \mathrm{hr})$, furnace exit gas temperature $\left(\mathrm{FEGT}=2000^{\circ} \mathrm{F}\right)$, and excess air levels $(25 \%)$ reflect utility industry experience on such fuels. More recently, efforts were made to evaluate slagging potential in the CTF. Utilizing information provided by Foster Wheeler Development Corporation, two slagging probes were designed, constructed, and positioned close to the flame region of the furnace. A simulated waterwall probe and a horizontal probe were installed just above the flame. Both slagging test probes are water-cooled to enable monitoring and maintaining surface metal temperatures between $500^{\circ}$ and $800^{\circ} \mathrm{F}$. 


\section{FLY ASH PARTICULATE CHARACTERIZATION}

Fly ash samples are obtained by various means at the inlet and outlet of the pilot-plant ESP or baghouse, as shown in Figure A-1. EPA Method 5 is used to establish particulate concentrations in flue gas. High-volume sample extraction and the pilot plant control device collection hoppers can provide larger samples for study. Particulate sizing and laboratory ash resistivity techniques used to characterize the fly ash from each test are described below.

\section{Five-Stage Cyclone System}

A five-stage cyclone system, shown in Figure A-5, is used to determine the size distribution of particulate entering the ESP. The system consists of five cyclones and a backup filter connected in series to provide five equally-spaced particle-size cuts on a logarithmic scale from 0.1 to $10 \mu \mathrm{m}$. The nominal flow rate for the system is $1.0 \mathrm{acfm}$. The five-stage cyclone system was designed to operate in-stack, but is operated out-of-stack (particulate-laden flue gas is isokinetically extracted from the stack using a sampling probe) at the EERC because of the small pipe diameters associated with the pilot-scale combustion equipment.

\section{Laboratory Resistivity Unit}

Bulk electrical resistivity measurements are made with an apparatus designed and built according to the ASME Power Test Code 28 that provides control of temperature and flue gas environment for the ash samples being tested. Temperature control is maintained by an oven consisting of two concentric cylinders separated by 3 inches of ceramic fiber insulation (Figure A-6). The outer cylinder is made of

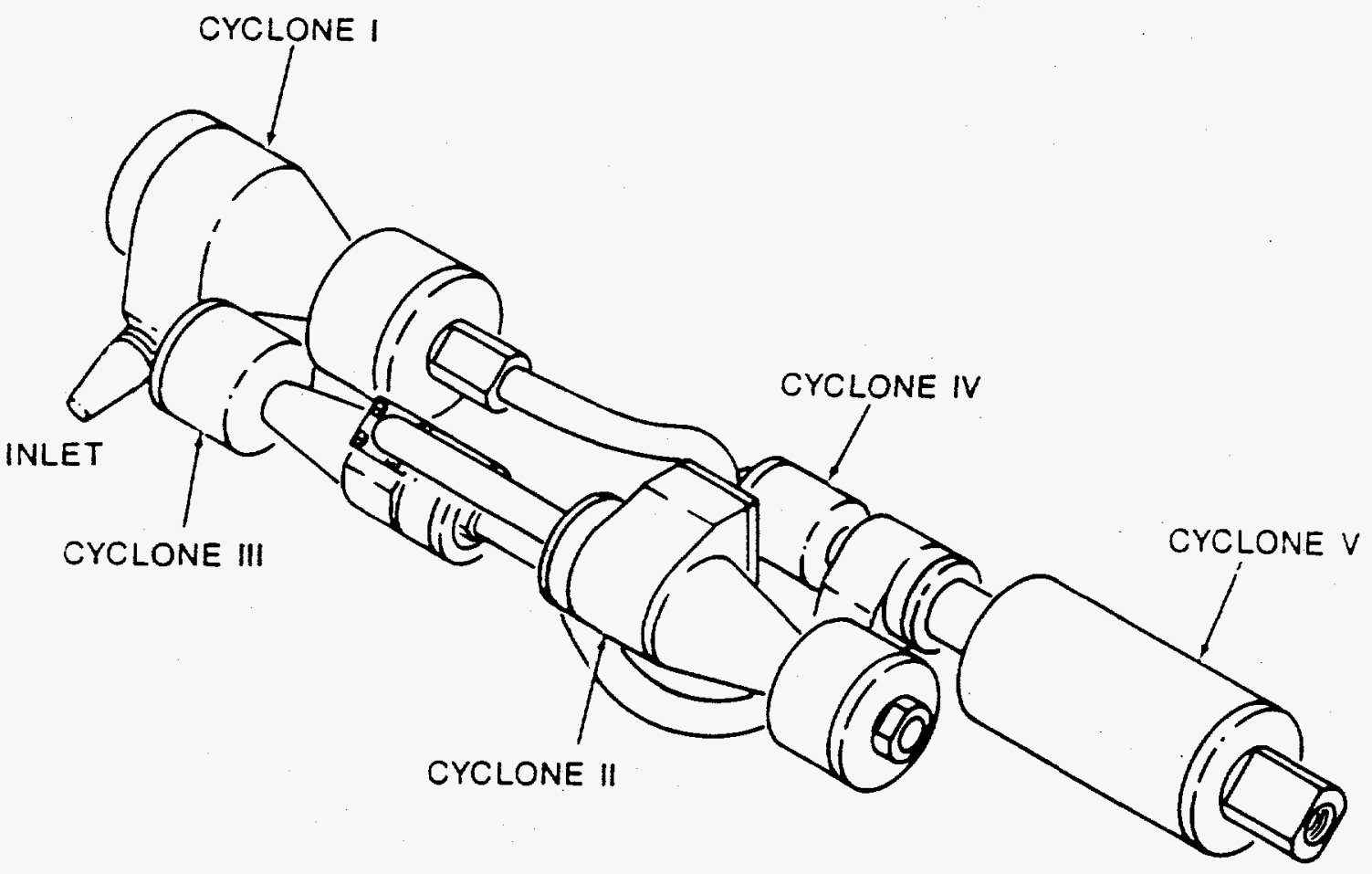

Figure A-7. Five-stage cyclone sampling system. 
mild steel and is 34 inches high and 16 inches in diameter. The inner cylinder is constructed of stainless steel and is 28 inches high and 10 inches in diameter. Heating is achieved with 3000-watt strip heaters placed around the outside of the inner cylinder. The oven can be heated to a maximum of $800^{\circ} \mathrm{F}$ in approximately $1 / 2$ hour and can maintain any temperature between room temperature and $800^{\circ} \mathrm{F}$. Oven temperature is measured with a thermocouple, and temperature control is achieved with an automatic controller. A second thermocouple with digital readout is mounted near the ash layer for a precise determination of the oven temperature. Flue gas components $\left(\mathrm{O}_{2}, \mathrm{CO}_{2}, \mathrm{SO}_{2}\right.$, and $\mathrm{N}_{2}$ from compressed gas cylinders) are metered with rotameters to match the flue gas concentrations in which the fly ash was collected. Humidity is controlled by bubbling the simulated flue gas through a constant temperature humidification bath. Sulfur dioxide and $\mathrm{CO}_{2}$ do not go through the humidity bath, but enter the simulated flue gas stream just prior to the oven.

Fly ash resistivity measurements are made using a movable disk electrode, as shown in Figure 7. This electrode was designed to put a pressure of $10 \mathrm{~g} / \mathrm{cm}^{2}$ on a layer of ash $5 \mathrm{~mm}$ thick. The ash sample container and the electrode are made of sintered stainless steel of 25 -micron porosity to allow contact between the ash and the flue gas. The electrode can be raised or lowered by a crank on the outside of the oven.

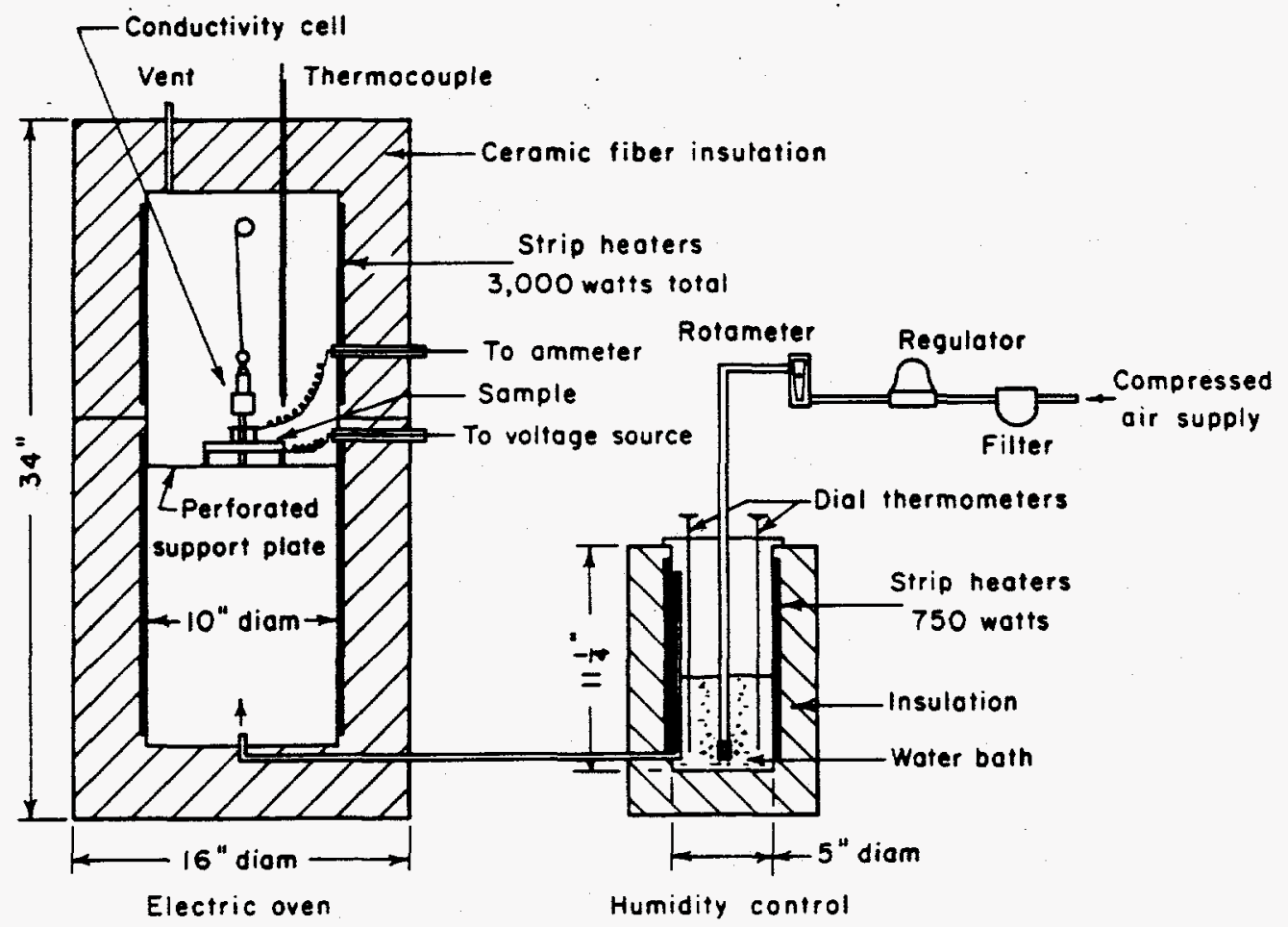

Figure A-8. Schematic of laboratory resistivity apparatus. 
A high-voltage supply with a range of 0 to 1200 volts is wired to the sample pan electrode. Current passing through the sample layer from the sample pan to the measuring electrode is measured by an electrometer capable of reading currents from $10^{-14}$ to $10^{-1}$ amperes. Coaxial cable is used on the voltage source and electrometer to shield against external noise.

A uniform ash layer is introduced to the conductivity cell and the electrode is carefully lowered onto the ash layer. The oven door is then closed and the temperature is set to $200^{\circ} \mathrm{F}$. After the oven has maintained the designated temperature for at least 40 minutes, 750 volts are applied to the $0.5-\mathrm{cm}$ ash layer. This produces a field strength of $1.5 \mathrm{kV} / \mathrm{cm}$. The current through the ash layer is measured with a high-sensitivity electrometer. The temperature of the oven is increased to the next higher temperature, after which there is a 40-minute waiting period to ensure that the ash layer has a uniform temperature. The test voltage is then applied, the current reading is recorded, and the temperature is increased to the next setting. One set of readings from $200^{\circ}$ to $750^{\circ} \mathrm{F}$ normally requires 8 to 10 hours to complete.

The fly ash resistivity (in ohm-cm) is calculated using the equation

$$
\rho=\frac{V A}{I I}
$$

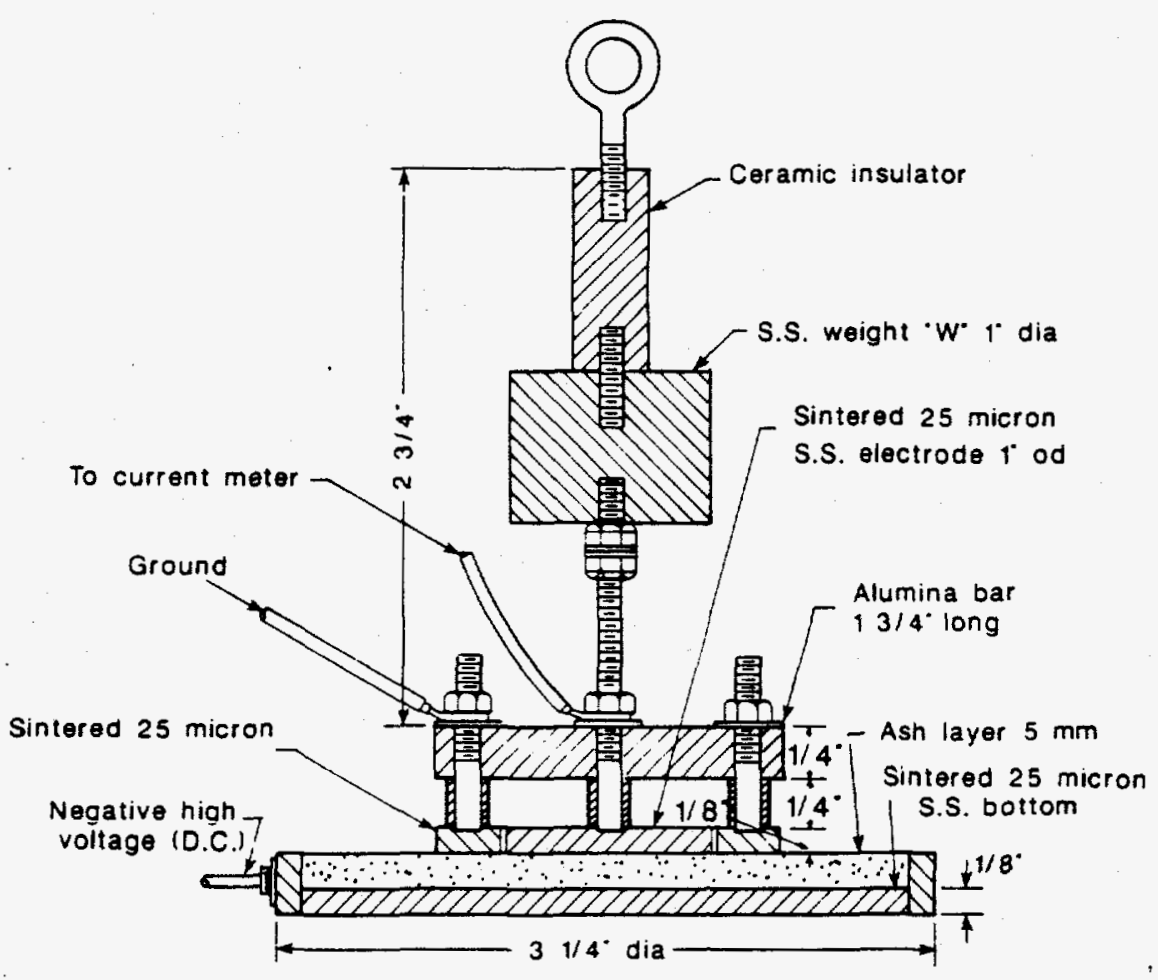

Figure A-9. Resistivity-measuring electrode. 
where $\mathrm{V}$ is the applied voltage (held constant at 750 volts), $\mathrm{A}$ is the area of the inner electrode $\left(5.07 \mathrm{~cm}^{2}\right), \mathrm{L}$ is the thickness of the ash layer $(0.5 \mathrm{~cm})$, and $\mathrm{I}$ is the measured current in amperes. For a given test, the data are presented as a plot of fly ash resistivity in ohm-cm versus temperature.

\section{ANALYTICAL PROCEDURES}

\section{Slurry Fuel Analysis}

The slurry fuel sample is analyzed to determine its proximate and ultimate analysis, heating value, and particle-size distribution.

Proximate analysis (moisture, ash, volatile matter, fixed carbon) is performed on the raw and treated fuel using a Fisher coal analyzer. The instrument determines moisture according to the ASTM D3302-74 standard method. Volatile matter is determined by heating the dried sample to $950^{\circ} \mathrm{C}$. The sample is covered during this process in order to exclude oxygen and prevent the sample from being ashed. Following the volatile matter determination, the sample is uncovered and combusted, and the ash is determined by ASTM D3174-73. Fixed carbon is determined by difference following the previously described methods.

Ultimate analysis determines carbon, hydrogen, nitrogen, sulfur, oxygen, and ash content in a sample. Carbon, hydrogen, and nitrogen (CHN) content are determined using a Leco ${ }^{\star} \mathrm{CHN}-600$ analyzer. Carbon and hydrogen are determined by infrared cells, and elemental nitrogen is measured by a thermal conductivity cell. This method gives the total percentages of CHN in the organic sample as analyzed and includes the carbon in carbonates and the hydrogen in the moisture and in the water of hydration of silicates. Sulfur is determined using a Leco ${ }^{\otimes}$ SC-132 sulfur analyzer. It operates on the principle of determining sulfur by combusting the sample in oxygen, forming sulfur dioxide, which is determined by an infrared cell detector. The level of chlorine in the CWF is determined by ASTM method D2361. Ash is determined by the ASTM Method described above under proximate analysis. Oxygen is determined by difference in order to achieve a balance for the ultimate analysis. Forms of sulfur are determined according to ASTM-D2492-80.

Gross caloric value is measured by ASTM Method D2015 using a Paar adiabatic calorimeter and master controller.

The particle-size distribution of the fuel is determined by wet-sieve analysis according to ASTM Method D410.

\section{Inorganic and Mineral Component Analysis}

\section{Slurry Fuel Ash Analysis}

Concentrations of major mineral oxides ( $\mathrm{Al}, \mathrm{Si}, \mathrm{Na}, \mathrm{Mg}, \mathrm{Ca}, \mathrm{P}, \mathrm{K}, \mathrm{Fe}, \mathrm{Ti}$, and $\mathrm{S}$ ) in the fuel ash are determined by $x$-ray fluorescence. The RDF slurry ash samples are prepared using the ASTM D3174 procedure. Analysis is performed using a Kevex $\mathrm{x}$-ray spectrometer. The elemental percentage is expressed as a weight percent of the total equivalent oxides.

Fusion temperatures of the RDF slurry ash are determined under oxidizing and reducing conditions in accordance with ASTM Method D1857 using a Preier/Mineco electric tube furnace. 


\section{Ash Deposit Characterization}

Chemical compositions of probe deposit and fly ash samples are determined by means of x-ray fluorescence (XRF). X-ray diffraction (XRD), which allows the identification of major crystalline forms, is used to support more quantitative SEM techniques in evaluating ash deposition phenomena. Identification, selection, and analysis of critical regions of the deposits are accomplished using SEM techniques.

A scanning electron microscopy point-count technique (SEMPC) is used to quantify the phases present in the deposit. The SEM microprobe system is a powerful tool that can be used to examine the microscopic features of deposits and fly ash and provide chemical analysis of points as small as $1 \mu \mathrm{m}$ in size. The system is automated and computer-controlled, which increases data manipulation and data storage capabilities. The SEMPC technique was developed at the EERC to systematically and quantitatively determine the distribution of phases in ash deposits and fly ash. The SEMPC technique provides information on the degree of interaction and melting of the deposited ash components and the abundance of crystalline, amorphous, and unreacted ash particles. The data obtained from the technique are critical in identifying the components in ash deposits that are responsible for deposit growth and strength development. In addition, viscosity distribution profiles can be calculated for the amorphous or liquid phases using SEMPC data. This information provides insight into the propensity of a particular ash to form a strong deposit.

The procedure for SEMPC analysis involves preparing a cross section of the sample by mounting the ash deposit sections in epoxy. The epoxy block is sectioned to expose the ash deposit material. The exposed section is then polished to provide a very smooth surface for examination with the SEMPC technique.

The polished sample is placed in the SEM, and a compositional analysis is obtained from a series of 250 grid points across approximately $35 \mathrm{~mm}^{2}$ of the sample. The Tracor Northern 5500 computer system differentiates between epoxy and deposit material and stores the chemical information. The stored chemical information is transferred to a microcomputer that identifies and quantifies the amorphous and crystalline components in the deposit. The crystalline components are readily identified as minerals based on chemical composition and molar ratios. The amorphous component is classified as either derived phases or unclassified material. Derived phases resemble their coal mineral precursor. Unclassified material has no crystalline structure and shows no molar ratios that conform to mineral formulas stored in the SEMPC program.

\section{Fly Ash Analysis}

The elemental oxide concentration of each sample is determined by XRF. As mentioned above, this analysis includes the major mineral oxides normally associated with fossil fuels.

The particle-size distribution of the fly ash can be determined by a number of methods. One method uses a Malvern ${ }^{\otimes} 2600$ c laser diffraction particle-size analyzer capable of measuring particle sizes from 0.5 to 564 microns (see Figure A-8). The Malvern ${ }^{\$}$ uses a He-Ne low-power visible wavelength laser that is first expanded and spatially filtered to provide a clean parallel beam. As particles pass through the beam, they scatter or diffract the light at different angles, depending upon their diameter: large particles scatter at small angles and vice versa. The scattered light is collected by a lens and brought to focus on a multielement solid-state detector that simultaneously measures the light at a number 
of angles. During analysis, the sample particles move rapidly through the laser beam. The results indicate the volume percentage distribution, as well as report the average particle size.

Trace element analysis of the flue gas is conducted by extractive sampling of the gas stream at the inlet and exit of a particulate control device using the tentative EPA Method 29 sampling train and subsequent analysis.

Tentative EPA Method 29 (currently being established for EPA by the EERC) multimetals train is the primary sampling procedure for determining trace element concentrations in the flue gas. The impinger train consists of a series of glass impingers filled with trapping solutions ending with a final moisture trap, vacuum pump, and dry gas meter. The filter assembly and impinger train are prepared by cleaning with brushes and hot, soapy tap water. Next, the train is rinsed three times in tap water and then three times in deionized (DI) water. All glassware, including quartz and teflon parts, are soaked a minimum of 4 hours in a $10 \%$ nitric acid $\left(\mathrm{HNO}_{3}\right)$ bath. After 4 hours, the glassware and Teflon parts are removed from the acid bath and are again rinsed in DI water three times. The sampling train is dried in as contaminant-free an environment as possible. The DI water is checked periodically for trace metal contamination.

A total of six impingers are included in the train. Impingers 1 and 2 are filled with $200 \mathrm{~mL}$ of $10 \%$ hydrogen peroxide $\left(\mathrm{H}_{2} \mathrm{O}_{2}\right)$ in a $5 \% \mathrm{HNO}_{3}$ solution. All trace metals, with the exception of elemental $\mathrm{Hg}$, will be captured in these impingers. Impinger 3 is empty to prevent any mixing of the two types of trapping solutions. Impingers 4 and 5 are filled with a $4 \mathrm{wt} \%$ potassium permanganate $\left(\mathrm{KMnO}_{4}\right)$ solution in $10 \%$ sulfuric acid solution. Impinger 6 contains silica gel to ensure that the flue gas is thoroughly dried before leaving the impinger train. The actual sampling procedure is similar to EPA Method 5 in that particulate matter is collected on a quartz fiber filter; however, in Method 29, vaporphase metals that penetrate the filter are collected in the impinger solutions downstream from the filter. Analysis of trace metals in the collected samples will be performed as indicated in Table A-1. Since mercury can exist as either elemental mercury or as an oxide, special care is required in sample preparation and analysis to distinguish and quantify these forms.

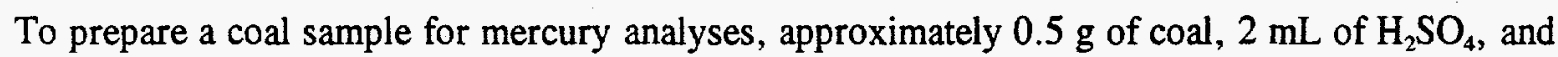
$2 \mathrm{~mL}$ of $\mathrm{HNO}_{3}$ are added to a microwave digestion vessel. The vessel is sealed, placed in the microwave, and heated to attain a pressure of 40 psi for 140 minutes. After the vessel is cooled to room temperature in an ice bath, an additional $2 \mathrm{~mL}$ of $\mathrm{HNO}_{3}$ is added. The vessel is then heated to attain a pressure of 80 psi for 70 minutes. The sample is again cooled, followed by reheating to 80 psi for 70 minutes. An additional three cycles of heating to a pressure of 100 psi for 40 minutes and subsequent cooling are performed. The final step in the procedure is heating to attain a pressure of 120 psi for 40 minutes. After the sample has been cooled, it is quantitatively transferred to a 50 -mL volumetric flask, brought to volume, and filtered.

Similarly to the coal samples, ash samples are also digested using a microwave digestion system. Approximately $0.5 \mathrm{~g}$ of ash, $3 \mathrm{~mL}$ of $\mathrm{HNO}_{3}, 3 \mathrm{~mL}$ of hydrochloric acid $(\mathrm{HCl})$, and $3 \mathrm{~mL}$ of hydrofluoric acid (HF) are added to a microwave digestion vessel. The vessel is placed in the microwave, heated to a pressure of 100 psi for 40 minutes, and then cooled to room temperature in an ice bath. Four percent boric acid $\left(\mathrm{H}_{3} \mathrm{BO}_{3}\right)(15 \mathrm{~mL})$ is then added to the vessel, which is heated to attain a pressure of 50 psi for 20 minutes cooled and reheated. The sample is quantitatively transferred to a $50-\mathrm{mL}$ volumetric flask, brought to volume, and filtered. 
To analyze the Method $29 \mathrm{H}_{2} \mathrm{O}_{2}$ solutions, $5 \mathrm{~mL}$ of sample is transferred to a 50 -mL test tube. A sufficiently sized tube is necessary to prevent the sample from overflowing during the effervescent neutralization step. The samples are placed in an ice bath and allowed to cool for 15 minutes. To decompose the $\mathrm{H}_{2} \mathrm{O}_{2}, 0.25 \mathrm{~mL}$ of $\mathrm{KMnO}_{4}$ solution is added. After cooling for 15 minutes, the procedure is repeated four times. As a final step, an additional $2 \mathrm{~mL}$ of $\mathrm{KMnO}_{4}$ solution is added in $0.5-\mathrm{mL}$ additions to provide an excess of reagent. After each addition, the samples are cooled and agitated. As a final step, $2 \mathrm{~mL}$ of hydroxylamine sulfate solution is then added in $1-\mathrm{mL}$ additions, (cooled and agitated after each addition) to reduce the $\mathrm{KMnO}_{4}$.

For the $\mathrm{KMnO}_{4}$ solutions, solid hydroxylamine sulfate is added to the sample to reduce the $\mathrm{KMnO}_{4}$ until no color persists and the $\mathrm{KMnO}_{4}$ residue is dissolved. The sample, which is usually in a 250 - or a $500-\mathrm{mL}$ volumetric flask, is brought to volume.

Mercury analyses at the EERC are done using a commercial cold-vapor atomic adsorption (CVAA) analyzer (Leeman PS200). In this instrument, a prepared sample enters the system and is mixed with a reducing agent (10\% stannous chloride) to form elemental mercury vapor. The mixture flows into a liquid-gas separator where nitrogen is introduced to carry the mercury vapor through a drying tube for water vapor removal. The dry vapor then enters one path of a double optical cell that has been optimized for fast response time and sensitivity. A mercury source, powered by a constant current power supply, delivers a stable source of emissions at $254 \mathrm{~nm}$. Absorbance by the mercury cold vapor is measured using a solid-state detector with a wide dynamic range. The resulting signal is referenced to the simultaneous absorbance of the pure carrier gas flowing through the second optical path under identical conditions. These signals are then sent to a computer system where the mercury concentration of the solution is calculated and reported. Although $0.1 \mathrm{ppb}$ is reported as the detection limit of the instrument, EERC personnel have determined that the instrument has a credible detection limit below $0.1 \mathrm{ppb}$.

To ensure the precision and accuracy of the instrument, it is calibrated on a regular basis using quality control standards. The calibration check standards are analyzed every five samples to check for instrument drift, and every ten samples a reslope is performed. All samples are run in duplicate, and one in every ten samples is spiked to verify analyte recovery.

\section{TABLE A-1}

Trace Element Analysis of Raw and Chemically Cleaned Coal

\begin{tabular}{ll}
\hline Parameter & Instrument \\
\hline Mercury & CVAAS $^{\mathrm{a}}$ \\
Selenium & HGAAS $^{\mathbf{b}}$ \\
Antimony, Arsenic, Cadmium, Lead & GFAAS $^{\mathrm{c}}$ \\
Chromium, Cobalt, Manganese, Nickel, Lead and Beryllium & ICAP-AES $^{\mathbf{d}}$ \\
Chloride & IC $^{\mathrm{e}}$ \\
\hline
\end{tabular}

- Cold-vapor atomic absorption spectroscopy.

b Hydride generation atomic absorption spectroscopy.

c Graphite furnace atomic absorption spectroscopy.

d Inductively coupled argon plasma-atomic emission spectroscopy.

- Ion chromatography. 


\section{Analytical Equipment for Trace Element Concentration}

A description of the analytical equipment used to determine trace element concentrations follows:

- Leeman Labs PS1000 sequential ICAP atomic emission spectrophotometer with integrated computer, autosampler, and Hildebrand grid nebulizer for quantitative multielement analysis. Purged optics allows for increased analytical capabilities by expanding the wavelength coverage to a range of $178-800 \mathrm{~nm}$.

- Perkin Elmer 5100 atomic absorption spectrophotometer with heated graphite furnace atomization and Zeeman background correction. This allows for quantitative trace element analysis at the parts-per-billion level for highly complex sample matrices such as coal and coal fly ash mixed acid digestions.

- Dionex 2120i dual-channel ion chromatograph with auto sampler and conductivity, UV/Vis, and electrochemical detectors for the quantitative analyses of anions and cations at the parts-per-billion level.

- Leeman Labs PS200 automated mercury analyzer based on CVAA for the determination of mercury with parts-per-trillion sensitivity.

- Varian AA1475 atomic absorption spectrophotometer equipped with a VGA-76 vapor generation accessory and electrically heated quartz cell for the determination of hydride-forming elements such as selenium, arsenic, and antimony.

\section{Leaching Potential of HAPS (SGLP, TCLP, LTL)}

To determine the leaching potential of the HAPs captured in the fly ash, a thorough materials chemical characterization will be initiated with a qualitative screening technique. Qualitative identification of elements present is particularly helpful in determining which elements need to be evaluated for leachability. This screening step provides information on elemental constituents present in individual materials. Identifying the chemical constituents in this manner has several advantages over the use of a predetermined list of analytes. These advantages include avoiding analyses of elements not present in large enough amounts to be of concern and avoiding the omission of analyzing other elements whose presence is unexpected. The qualitative screening is followed by quantitative analysis using more sensitive techniques, such as flame and graphite furnace atomic absorption spectroscopy, inductively coupled argon plasma emission spectroscopy, ion chromatography, and other instrumental and classical analytical techniques. These techniques, coupled with appropriate dissolution techniques, will be used to determine the concentrations of the chemical constituents in the bulk materiais.

The chemical characterization scheme for utilization-disposal also includes an evaluation of the leaching characteristics of the materials. Leaching characteristics are very important for environmental and health reasons, both in disposal and utilization scenarios. The leaching characterization protocol developed at the EERC includes the use of both short- and long-term leaching procedures and a 
mineralogical evaluation of the leached material following long-term leaching. The leaching procedures used can be summarized as follows:

- The toxicity characteristic leaching procedure (TCLP)

- The EPA regulatory test for hazardousness of materials to be disposed in a sanitary landfill

- Short-term ( $<48$ hours) leaching with a predefined leaching solution

- The synthetic groundwater leaching procedure (SGLP)

- Developed at the EERC

- Short-term leaching with leaching solution determined by the type of water expected to contact the used or disposed material

- The long-term leaching procedure (LTL)

- Developed at the EERC

- Long-term leaching procedure ( $>48$ hours) with leaching solution identified for the SGLP with leachate analysis at time intervals to evaluate changes in leachate quality

There are two important reasons that the TCLP alone may be inappropriate and provide incomplete or inadequate leachate characterization information. First, the TCLP utilizes an acidic solution containing acetic acid. The use of acetic acid as a leaching solution is, by EPA definition, designed to simulate the leaching a waste will undergo in a sanitary landfill. Under utilization and many disposal scenarios, the water to contact the by-product is extremely unlikely to contain acetic acid. The actual $\mathrm{pH}$ and chemistry of the leaching fluid likely to contact the by-product must be considered in order to perform a laboratory evaluation of leaching potential that will provide information pertinent to commercial applications. If it is the case that rainwater or alkaline water will be doing the actual field leaching, the solution used in the lab must exhibit a similar chemistry. Rainwater can often be simulated by a neutral solution (distilled water). The SGLP will be performed in addition to the TCLP to provide a complete and realistic evaluation of the short-term leaching characteristics of the materials selected for the study. Results of these two short-term leaching procedures will be compared and evaluated along with results of long-term leaching procedures. The use of a long-term leaching procedure addresses the second potential shortcoming of leaching evaluation by TCLP only. Combustion by-products, including fluid-bed combustion (FBC) by-products, may change mineralogical composition owing to hydration reactions upon contact with water and interaction between different minerals and constituents of the by-product or other added material in the product. These chemical reactions can have a significant impact on the leachate generated and must be considered to fairly evaluate these materials for use or disposal. Many of the reactions are slow and can take up to 30 days to exert an effect, as demonstrated by previous research projects at the EERC. The effect can be more than an order of magnitude with respect to solution concentration of several potentially hazardous elements. LTL procedures (30 and 60 days) will be used to evaluate long-term phase changes and to establish the direction of concentrations of trace elements as equilibrium is approached, providing more realistic information regarding the potential mobility of elements in a material under disposal conditions. X-ray diffraction will be performed on the original material and the leached material from long-term leaching to aid the evaluation of trace element mobility in this material. 
APPENDIX B

DESCRIPTION OF THE CONVERSION AND ENVIRONMENTAL PROCESS SIMULATOR (CEPS) 


\section{DESCRIPTION OF THE CONVERSION AND ENVIRONMENTAL PROCESS SIMULATOR (CEPS)}

The Energy \& Environmental Research Center (EERC) has been performing controlled combustion tests using bench- and pilot-scale test combustors for many years. These include drop-tube furnace systems (atmospheric and pressurized) that burn grams of fuel per minute and pilot-scale units that burn 50-75 pounds of fuel per hour. Recently, the EERC has built an intermediate-scale combustor that will effectively operate at 1-5 pounds of fuel per hour. This system (Figure 1) is termed the Conversion and Environmental Process Simulator (CEPS).

The CEPS is an extremely versatile system which can generate realistic combustion test results for a variety of fuels and combustion conditions. The intermediate size of the system and its relatively simple operation ensure adequate quantities of actual flue gas and ash for analysis in a relatively short period of time. Specific applications for this system include fuel and combustion system impacts on air pollutant formation and prevention, residual ash disposal and reuse, combustion rates and efficiencies, and furnace slagging and fouling. The CEPS is especially designed for sensitive measurement of trace element species in flue gas with detection limits less than one part per million. Combustion testing of both coal and fuel oil under various conditions has been successful to date. However, the CEPS is not limited to these fuels. Other fuels that could be tested include coal water fuels, petroleum coke, oremulsion, black liquor, biomass such as wood pellets, hay, alfalfa, or tree bark, and waste materials such as sludge and municipal solid waste. The CEPS is currently equipped with a baghouse, but soon will also have the capability of operating with a small wet scrubber system. These scaled-down versions of particulate and $\mathrm{SO}_{2}$ control systems will be used to determine emissions factors and removal efficiencies for toxic metal and other air toxic emissions.

When designing the CEPS, it was found that many similar intermediate-scale furnaces currently in operation have trouble attaining and maintaining high gas temperatures in the main combustion zones from the fuel alone. Acute control of gas temperatures and composition throughout the CEPS furnace is possible, independent of the heat capacity of the fuel, because of the external heating capacity of CEPS. Heating elements line the main furnace, convective pass section and baghouse chambers. Temperatures of the flue gas (approximately 5-10 scfm) can attain a maximum of $1500-1600^{\circ} \mathrm{C}\left(2732-2912^{\circ} \mathrm{F}\right)$ in the radiant section and can be maintained at $760-1200^{\circ} \mathrm{C}\left(1400-2200^{\circ} \mathrm{F}\right)$ in the convective pass section and $120-250^{\circ} \mathrm{C}\left(248-482{ }^{\circ} \mathrm{F}\right)$ in the baghouse with the capability to go higher. The CEPS was also designed with the sampling of trace elements in mind. The entire system is lined with either ceramic or refractory material, eliminating the possibility of reaction with and contamination of metal surfaces. There is ample access for sampling, observation, and optical diagnostics through access ports located throughout the CEPS. A PC displays and records temperatures, gas flows, feed rates and flue gas compositions. Flue gas $\left(\mathrm{O}_{2}, \mathrm{CO}_{2}, \mathrm{CO}, \mathrm{SO}_{2}\right.$, and $\left.\mathrm{NO}_{\mathrm{x}}\right)$ compositions are sampled from ports in the radiant section and after the collection device.

The CEPS is a down-fired design for nominally top-firing $4.0 \mathrm{lb} / \mathrm{hr}(1.8 \mathrm{Kg} / \mathrm{hr})$ of pulverized coal or $1.5 \mathrm{lb} / \mathrm{hr}$ oil with a heat output of $-30,000 \mathrm{Btu} / \mathrm{hr}$. Several injection systems allow other solid or liquid fuels to be utilized. It is a modular system capable of simulating conditions of both the radiant and convective sections of a full-scale utility boiler. The electrically heated 12 foot vertical radiant furnace portion has an inside diameter of 6 inches for the first 9 feet, with the final 
heated section diameter reduced to 3 inches. The radiant zone exit is through a horizontal 1.5-inch-inside-diameter ceramic tube. A portion of the particulate is removed before going onto the convective pass section, which includes an optional ash-fouling test section. From the convective section, the flue gas flows through several refractory lined heat exchangers, the particulate collection device, an air eductor, and a stack that exits through the roof of the building.

The combustion air is split into primary and secondary air. $20-25$ percent of the air is introduced into the system as primary air and is used to carry the fuel into the CEPS. The secondary combustion air is preheated to a maximum of $850^{\circ} \mathrm{C}$ and can be introduced into the CEPS vertically or tangentially. Five electrically heated furnace sections comprise the main portion of the radiant furnace section and are constructed using a combination of ceramic tubes set into cast abrasion-resistant refractory. The refractory sections have access ports that are used for pressure and temperature measurements, injection of solids or gases, sampling of gaseous or particulate emissions, deposition, observation and optical analyses. The ceramic tubes are exposed to molybdenum disilicide heating elements allowing operation to $1500^{\circ} \mathrm{C}$. High temperature, fibrous insulating boards surround the high temperature components housed inside the stainless steel shells.

At the exit of the radiant section is a bottom (unheated) furnace section that is designed to remove and collect the larger ash particles prior to entering the horizontally oriented convective pass. The convective pass is about four feet in length and constructed of a combination of ceramic tubing, refractory, and high temperature fibrous insulating boards. There is the capability for studying deposition in the convective pass with two in-series highly instrumented air-cooled probes.

After the convective section, flue gas flows through a series of heat exchangers and then on to the particulate control device, which is either a baghouse, wet scrubber, or a cyclone. Flue gas temperatures are well-controlled going into the control device section for typical operation between $250-350^{\circ} \mathrm{F}$ and flexibility has been built into the system to allow experimentation at even higher flue gas temperatures. Beyond the control device the flue gas proceeds through an air eductor and up to a stack through the top of the roof of a new pilot plant facility at the EERC. The system is designed so that the control devices can be interchanged without major system modifications.

\section{Sampling and Analysis}

The CEPS is well suited for gas-particulate sampling and is routinely used for sampling air toxic metals. The sampling of particulate and vapor species from flue gas for testing performed on the CEPS is done, using the EPA Method 29, as described during its development by Ward (REF FPT 39, 1-3, 1994, pp. 259-263). For this method, isokinetic sampling of the flue gas is performed at typical flue gas temperatures of about $450^{\circ} \mathrm{F}$. For some of the experimental apparatus, quenching is required to keep the temperature low enough for the method. All filter housings, extraction probes and most other sampling parts are made of either glass or Teflon coated. Duplicate runs are made for all sample collections and strict cleaning procedures, as required by Method 29, are followed for all glassware, for added quality control. Also, for the experimental purpose of studying partitioning, cyclones are sometimes used to size segregate the particulate before entering the $.4 \mu \mathrm{m}$ filter housing of the sampling train. 
The typical EPA Method 29 sampling train consists of a quartz sampling probe that is inserted into the flue gas stream at the point of interest. Attached to the probe is a heated filter housing followed by a series of impingers, a dry gas meter and a vacuum pump. A total of six impingers is included in the sampling train. Impingers one and two are filled with $100 \mathrm{~mL}$ of $10 \%$ hydrogen peroxide $\left(\mathrm{H}_{2} \mathrm{O}_{2}\right)$ in $5 \%$ nitric acid $\left(\mathrm{HNO}_{3}\right)$ solution. Impinger three is empty to prevent any mixing of the two types of trapping solutions. Impingers four and five are filled with $4 \%$ potassium permanganate $\left(\mathrm{KMnO}_{4}\right)$ in a $10 \%$ sulfuric acid $\left(\mathrm{H}_{2} \mathrm{SO}_{4}\right)$ solution. Impinger six contains silica gel to ensure the flue gas will be thoroughly dried before it exits the impinger train. Method 29 specifies an additional dry impinger prior to the first hydrogen peroxide-nitric acid impinger. This dry impinger is removed from the condensation train because $\mathrm{SO}_{2}$ absorbed in the dry impinger could reduce some of the oxidized mercury to elemental mercury. To eliminate this possibility, the first impinger is usually removed from the train. The EPA does not claim that the Method 29 procedure speciates between oxidized and elemental mercury, but other evidence has indicated that much of the oxidized mercury will be trapped in the peroxide impingers and the majority of the elemental mercury in the permanganate impingers.

For trace element analyses graphite furnace atomic absorption spectroscopy (AA) is used to analyze coals, sorbents, and particulate samples from filters or multicyclones for $\mathrm{As}, \mathrm{Cd}, \mathrm{Cr}$, and $\mathrm{Pb}$; hydride generation $\mathrm{AA}$ for $\mathrm{Se}$; coal-vapor $\mathrm{AA}$ for $\mathrm{Hg}$; and inductively coupled argon plasma atomic emission spectroscopy for $\mathrm{Ni}$. Impinger solutions are analyzed for $\mathrm{Se}$ and $\mathrm{Hg}$ using hydride generation and cold-vapor AA, respectively. Major and minor elemental compositions for coal ash and combustion ash are determined by energy-dispersive $\mathrm{x}$-ray fluorescence (XRF). 


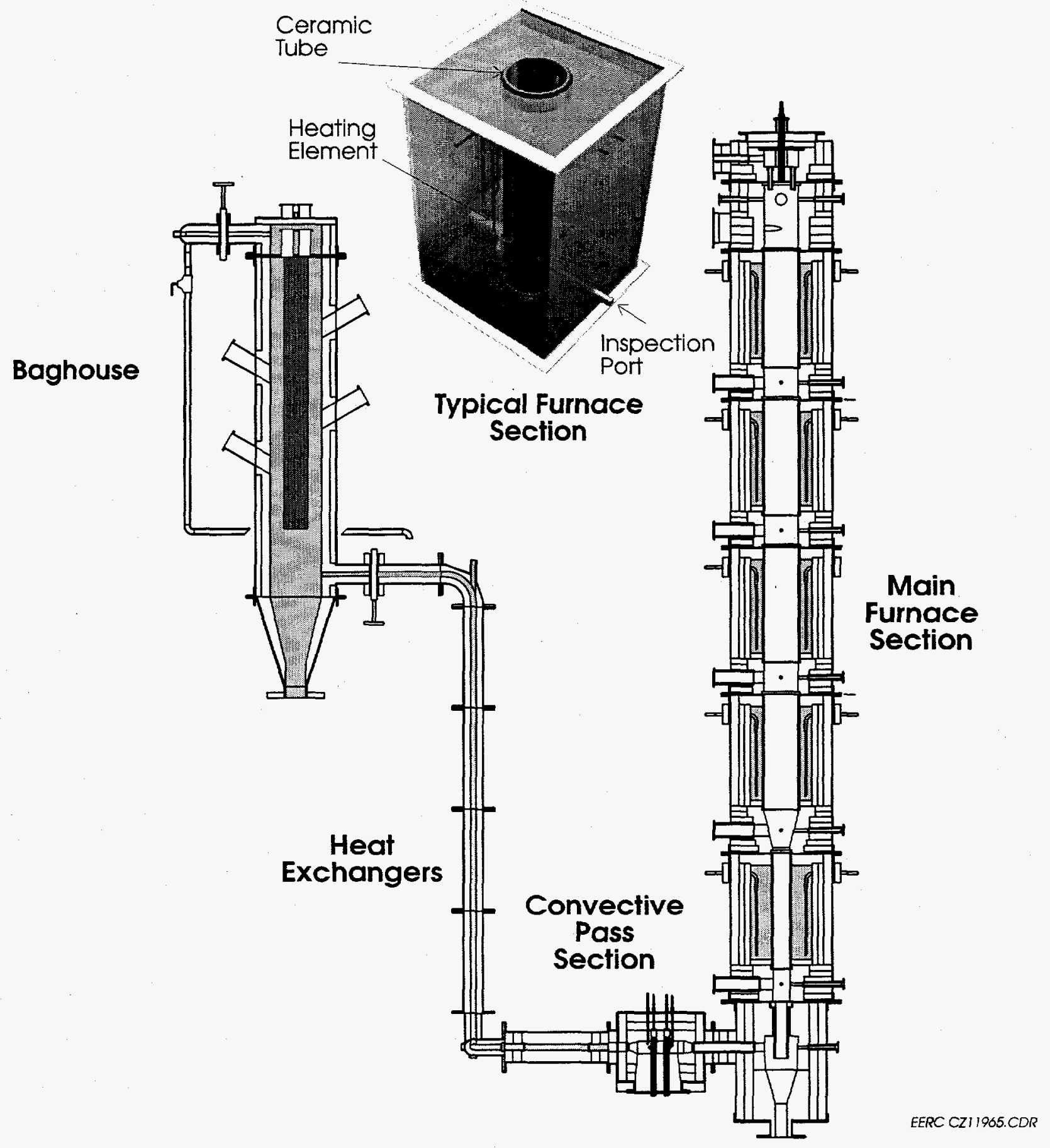

Design sketch of the Conversion and Environmental Process Simulator (CEPS) showing the main and convective pass section, heat exchangers, and baghouse 